\title{
Propiedades narrativas de la letra en el cómic
}

\author{
Octavio Beares
}

Octavio Beares San Martín (Oviedo, 1970) es licenciado en Geografía e Historia por la Universidad de Santiago de Compostela, y diplomado en Restauración y Conservación de Bienes Culturales por la Escuela Superior de Conservación y Restauración de Pontevedra. Comienza a escribir sobre cómics en su blog personal, El Octavio pasajero, y posteriormente en el blog Serie de Viñetas, especializando esta bitácora del site Gente Digital en historieta. Colabora en medios digitales como Culturamas o la revista $\mathrm{Vi}$ ñetas en Palabras. Cofundó en 2012 el blog Quadriños, del diario digital Praza Pública. Ha escrito sobre historieta en medios impresos (puntualmente en Guia Cicerone y Xornal de Galicia, en Rockdelux entre 2011 y 2012) y desde 2009 realiza una sección quincenal sobre cómic en Faro de Vigo, donde también colabora como crítico de música. En 2013 participa en el magacín "A estación”, de Radio Redondela, hablando de tebeos. Ha organizado los Primeiros Encontros coa banda deseñada. O cómic no museo, para el Museo de Pontevedra, en 2012, y para el mismo museo comisaría en 2014 la exposición Do cómic á novela gráfica. A banda deseñada en España no s. XXI. Codirige CuCo, Cuadernos de cómic. 


\title{
Resumen
}

En el presente trabajo propongo un estudio de las propiedades de la letra escrita en su función icónicanarrativa. Una función que se manifiesta en modos diversos y que se tratan separadamente: el tamaño de la fuente escrita entendido como ardid narrativo; las funciones de la caligrafía; aspectos relativos a modos de expresión temporal o espacial mediante la grafía.

Por último me detengo en analizar el papel de la letra en el cómic contemporáneo, contemplando la vigencia de los aspectos analizados previamente en la producción de nuestro presente.

\begin{abstract}
In this essay I propose a studio of narrative properties of lettering in comic art. A narrative function with some different aspects or modes: the font size as a matter of narrative content, the calligraphy functions and aspects like the expression of time and space with the written word in comic.

Finally this work meets the actual moment in comics and analyzes all those aspects seen before, in the production of our present.
\end{abstract}




\section{Propiedades narrativas de la letra en el cómic.}

La naturaleza de la escritura, en tanto que elemento de composición visual en la historieta, le otorga unas características específicas, acaso inexistentes en otras artes (o carentes del variado y necesario desarrollo que la naturaleza propia del cómic propicia). En este sentido ahondamos a continuación, más allá de los modos de reproducir la letra escrita en el cómic, y de las variadas posibilidades que of rece la ubicación de dicha letra en la página. Me centraré en las propiedades que la letra en el cómic ostenta en tanto que signo gráfico con facultades narrativas en sí mismo.

Para ello me detengo en tres aspectos bien diferenciados y que atienden a: la función narrativa del tamaño de la fuente y su variabilidad, la caligrafía o el aspecto visual de la letra escrita en una historieta y, finalmente, a la letra como expresión espacial y temporal en la historieta. A modo de epílogo observaré con algunos ejemplos al elemento textual en el cómic contemporáneo.

\section{Funcionalidad Narrativa del tamaño de la FUENTE ESCRita.}

Cabe entender dos funciones principales de la letra dentro de una narración gráfica, si atendemos al tamaño que se otorga a la fuente: por un lado, la variabilidad del tamaño físico del dibujo de la letra podrá ser indicativo de volumen sonoro. $Y$ por otro, en un ardid a mi entender muy específico y difícilmente trasladable a otro medio, se ha empleado enfáticamente el recurso de variar el tamaño de la fuente.

Respecto al primer caso, el autor puede jugar con el tamaño de la letra para expresar un aumento de volumen. Podremos recordar el ejemplo de la FIG. 1, ejemplo temprano (Thimble Theater, de Elzie Crisler Segar - 1894-1938 - la serie en cuyas viñetas nacería en 1929 Popeye). Un grito es sugerido en la primera viñeta, el de Olive, con una grafía ostensiblemente mayor que la de las líneas de diálogo restantes.

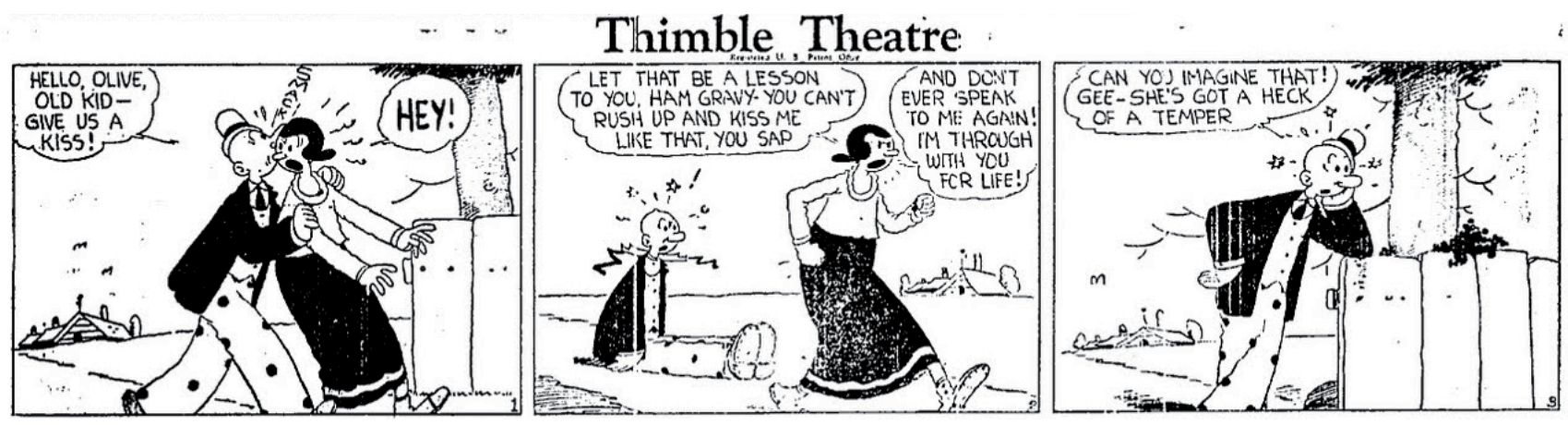

FIG. 1. Thimble Theater. E.C. Segar, 1926.

Pero el recurso como ardid narrativo va más allá en la FIG. 2, perteneciente al número 121 de la serie Amazing Spiderman, de Gerry Conway (1952), Gil Kane (1926-2000) y John Romita (1930). Hay que situar la escena: el villano, uno de los más peligrosos enemigos del hombre araña en tanto que conoce la identidad secreta del héroe, acaba de asesinar a la novia de aquel. Spiderman, pleno de dolor e ira, se ensaña con el criminal. Nada más lejos la acción de la justicia blanca, ponderada y civilizada de los clásicos superhéroes. Peter Parker, el hombre bajo la arácnida máscara, sufre y quiere venganza, y propina a su aturdido oponente una paliza rayana en la crueldad. Añadamos la nota frívola: su acción termina mal para el héroe, como se aprecia en la última viñeta, y la pelea continuará varias páginas más. 

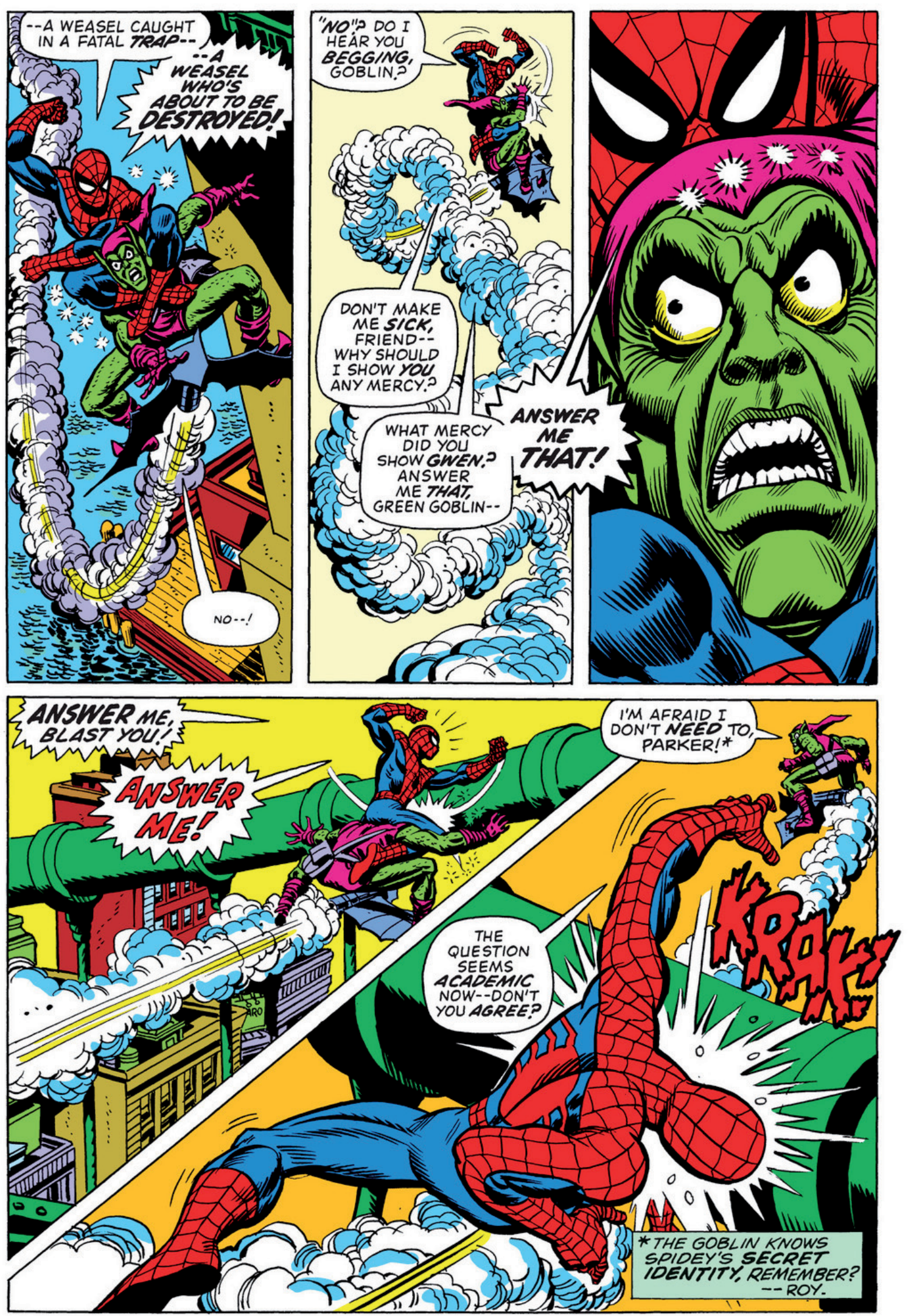

FIG. 2. Amazing Spiderman vol.1 n. 122 , Gerry Conway, Gil

Kane y John Romita, 1973. 
En lo que a elementos escritos respecta, la secuencia está planificada con un dramatismo e intensidad evidentes. Mientras golpea Spiderman no se contenta con noquear al malvado, sino que le increpa sin descanso en un crescendo sonoro, fluctuando su oratoria del tono medio, increpante e interrogante, hasta el grito herido y furioso que ya no busca respuesta sino desahogo. Más allá de que ello se refuerce con el dibujo del propio globo de diálogo, estrellado en los momentos que percibimos como de grito intenso, la idea se acentúa con el tamaño de la propia fuente escrita. Posiblemente el lector puede sentir el profundo aullido de ese "Answer me!" final (acentuada la emoción con el color rojo empleado). También seremos capaces de "musicalizar" la intensidad del volumen oscilante de las frases a lo largo de toda la escena.

Evidentemente, y en oposición al ejemplo que ilustramos, cabe también indicar que la disminución de la fuente puede obrar en un sentido práctico análogo, si bien en modo contrario, indicando un volumen que baja, un susurro, un sonido lejano menos perceptible, etcétera. Esta propiedad que entraña la elección de un mayor o menor tamaño de la letra escrita es más intensa y diversa en lo que atañe a las onomatopeyas. Merece la pena detenerse en sus cualidades narrativas derivadas de la gran variedad y capacidad combinatoria que el empleo de onomatopeyas ofrece al autor: estamos hablando de los signos de escritura más claramente sometidos a una impronta icónica. Al constituir palabras para reflejar sonidos inarticulados, gran parte de su función narrativa deriva del diseño gráfico que el autor le otorgará. La onomatopeya, en fin, podría ser antes dibujo que texto escrito.

Al mismo tiempo, para describir un sonido podemos observar diferentes modos de utilizar las onomatopeyas, que pueden restringirse a una por viñeta o utilizar varias en una sola imagen, o abundar en signos onomatopéyicos en un recorrido de varias viñetas. Buen ejemplo del empleo estratégico de una única onomatopeya es el citado en la FIG. 2, donde el Hombre Araña acaba chocando contra una tubería. "KRAK!" posee en sí mismo una cualidad fonética que nos informa de la severidad del choque. Pero además la forma de esa palabra es elocuente, de modo que el significado queda ilustrado por el trazo.

Uno de los autores que más reconocemos en el uso de onomatopeyas es George Herriman (1880-1944) en Krazy Kat. La FIG. 3, muestra en su viñeta central circular una de las imágenes más famosas en la historia del cómic, donde el ratón Ignatz apedrea con un ladrillo a Krazy. Dos onomatopeyas distintas en una misma viñeta articulan la acción, perfilan un lapso de tiempo: "zip", ladrillo arrojado, y "pow", choque con la mollera del felino.

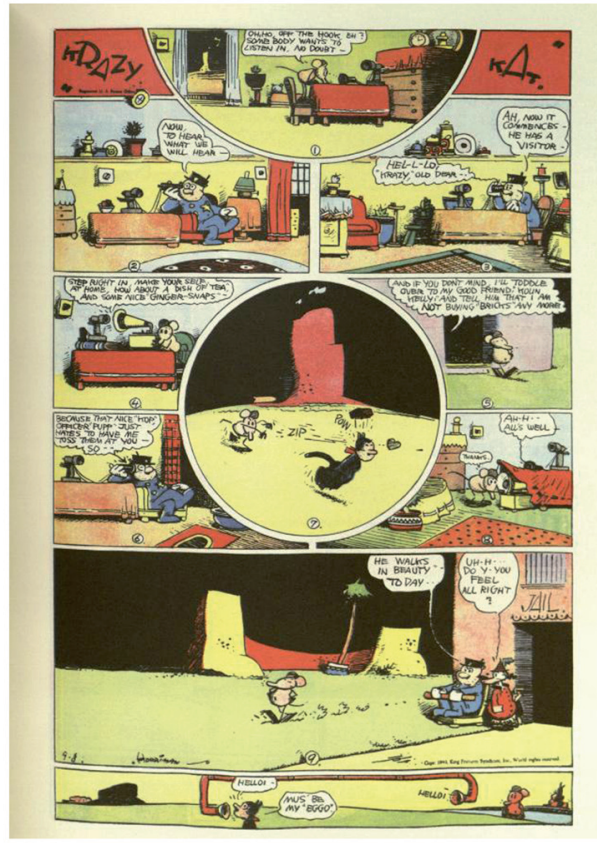

FIG. 3. Krazy Kat, George Herriman, 1940. 
Sin embargo aquí poco tiene que ver el tamaño de la fuente, salvo en relación con las líneas de diálogo, menores respecto a las onomatopeyas. Por el contrario la FIG. 4 nos sirve para ilustrar tanto una disposición de múltiples onomatopeyas dentro de una secuencia, como la continuidad del efecto onomatopéyico en una sucesión de viñetas. Se trata de Daredevil n. ${ }^{\circ}$ 187, de Frank Miller (1957) a cargo del guión y el abocetado y Klaus Janson (1952) en el dibujo y color. Cuatro viñetas de formato apaisado (panorámico) en cuyo curso el héroe sufre una distorsión auditiva. Daredevil es el superhéroe ciego que suple su falta de visión con un desarrollo sobrehumano de sus demás sentidos. Capaz de escuchar los latidos de un hombre, o el más mínimo movimiento a su cercanía, en esta historia pierde el control de semejante habilidad. El sonido invade al héroe atronándole con más y más intensidad, haciéndole percibir los bocinazos de la calle de un modo cada vez más ensordecedor.
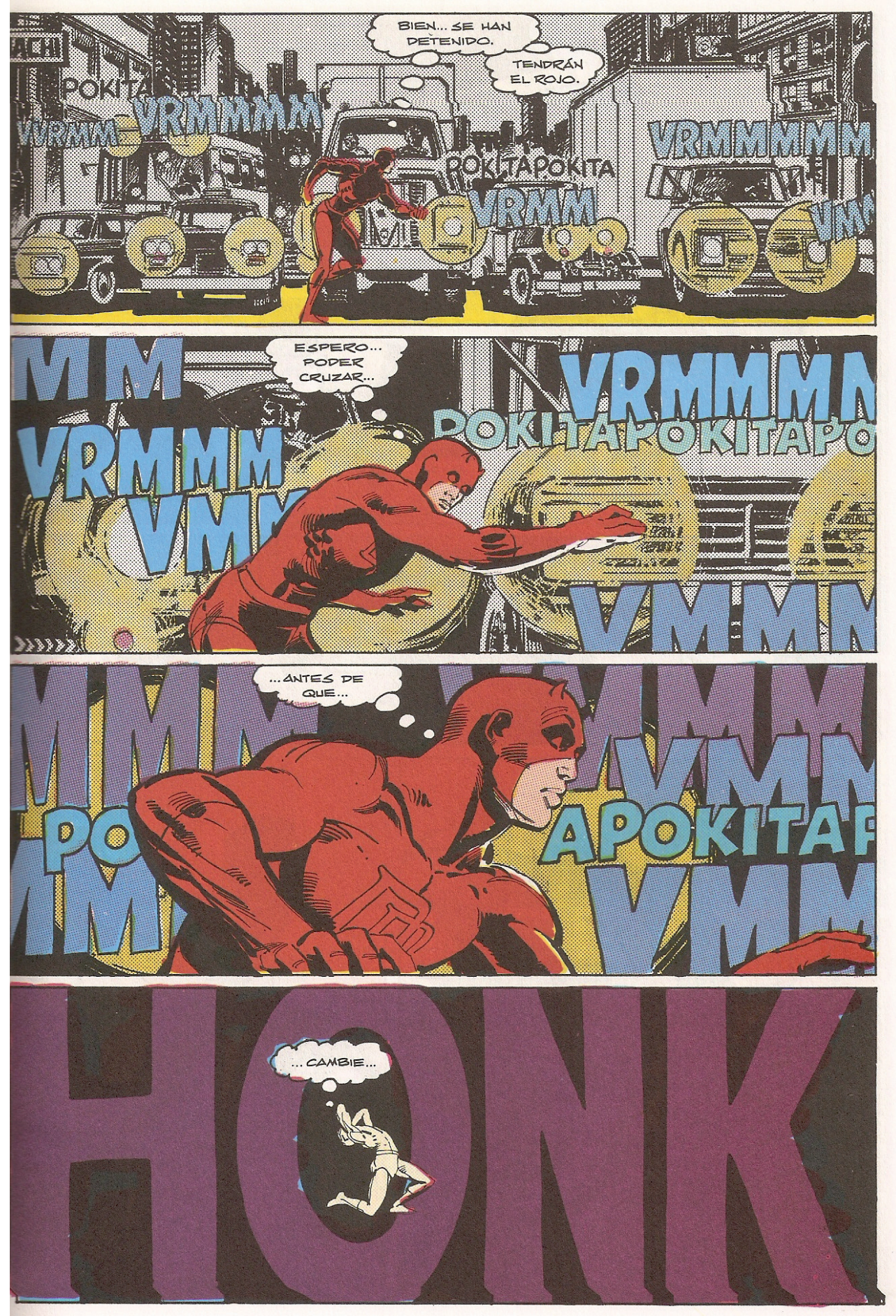

FIG. 4. Daredevilvol. 1 n.o 187, Frank Miller y Klaus Janson, 1982. 
Si analizamos las tres primeras viñetas una por una, aisladamente, contemplamos cómo Miller emplea onomatopeyas de diferentes tamaños para plasmar los ruidos de la calle dentro de la viñeta. Sonidos diferentes, unos estrepitosos, otros menos, una sinfonía cacofónica que queda retratada (dibujada, en efecto) con esa elección no arbitraria de tamaños diversos. Pero si al tiempo observamos la página como un todo, el empleo de las onomatopeyas muestra su contenido narrativo completo. Fijémonos antes en lo estrictamente escrito: "vrmmm", "honk", "pokitapokita", ¿qué transmiten estos tres términos así aislados? Nada. Fonéticamente hasta pueden resultarnos graciosos. El dramatismo lo acentúa el diseño gráfico; el progresivo aumento del tamaño de la fuente escrita; el acercamiento a la figura del héroe al primer plano en un efecto de "zoom"; la supresión paulatina de toda referencia gráfica del lugar en que la acción externa se desarrolla (lo vemos en la primera viñeta, donde el superhéroe está cruzando un semáforo) para interiorizar la acción en los sentidos desbocados, hirientes, que sufre Daredevil. La viñeta final resulta demoledora por contraste. Frente a la multitud de onomatopeyas se pasa a una única, enorme. Se elimina toda referencia al mundo real (en la tercera aún entendemos dos haces de los faros de un vehículo) y la figura escarlata, tras un paulatino acercamiento de plano de la secuencia previa, se nos representa minúscula y ahogada dentro del estruendo, uno ya informe, no una sinfonía sino una frecuencia dolorosa, absoluta, que sencillamente noquea al personaje.

Todos estos ardides de dibujo a los que se somete la grafía pretenden y logran narrar con letras entendidas como imágenes. Con su disposición, con su forma y tamaño. También debemos advertir que el color de la letra es expresivo y narrativo: recordemos el "Krak!" en la FIG. 2, y en el caso de Daredevil también es importante el color elegido para cada onomatopeya, con un degradado tonal de gamas frías a otras de mayor calidez.

Una vez comprobada la capacidad narrativa del tamaño de la onomatopeya dibujada como expresividad de intensidad sonora, cabe señalar que el cómic también ha generalizado un recurso acaso más intransferible, como es el aumento del tamaño de la fuente con un sentido enfático. Es interesante porque en este caso no estamos ante un truco narrativo ni refleja intensidad de volumen. La acentuación enfática del mensaje escrito recurre muy a menudo en la historieta a aumentar ligeramente el tamaño de determinadas palabras. Usar "negritas". No pretende así el autor indicar un aumento de volumen sonoro, sino simplemente reforzar visualmente aquellas palabras sobre las que considera que recae una idea fundamental.

La FIG. 5 pertenece a Capitán América n. 9 de Ed Brubaker (1966) y Michael Lark (1966) y en sus líneas de diálogo (la rotulación castellana respeta los modos de la original americana) entendemos claramente cómo se emplea tal recurso.

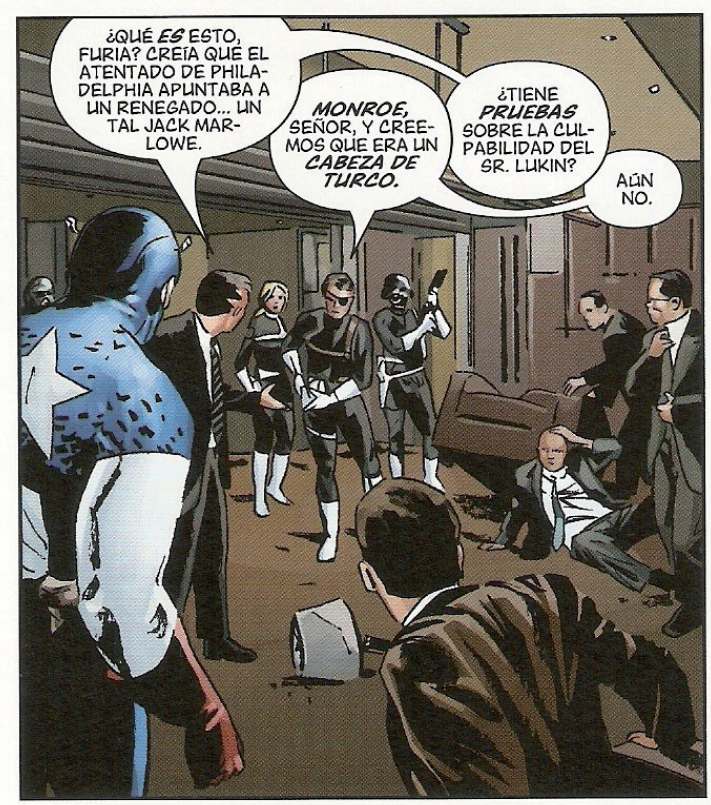

FIG. 5. Capitán América vol.5 n. 9 9, Ed Brubaker y Michael Lark, 2005. 
¿Tiene un sentido dentro de la narración el uso de negrita y acaso un mayor tamaño en la fuente de las palabras "es", "pruebas", la expresión "cabeza de turco" o uno de los dos nombres propios que se están verbalizando? No, esta cualidad visual no nos está indicando aquí que el tono sube, que se griten los personajes o que decrezca su volumen sonoro, sino que el ardid focaliza aquellos sustantivos, verbos, nombres propios y expresiones que los autores quieren que entendamos como los mensajes principales. Significativo es el caso de los nombres propios, porque es evidente que "Jack Marlowe" carece de importancia frente a "Monroe", y es evidente no por otra cosa que porque el nombre "Monroe" se ha escrito con mayor tamaño, en negrita.

\section{Funcionalidad de la CALIGRAFía: El TRAZo y EL “Dibujo” de la FUENTE.}

La letra escrita posee una capacidad funcional así como una cualidad expresiva y narrativa en atención a su trazo caligráfico. Lo hemos visto ya en varios ejemplos anteriores: la forma en que una palabra es dibujada por el rotulista adquiere connotaciones que narran o aportan contenidos narrativos expresando ideas que no necesitan más enfatización, perfectamente delimitadas por esa forma. Se puede, en este sentido, aplicar un empleo puntual de ardides de dibujo sometiendo la grafía a un cambio, dentro de un contexto, en un determinado momento de la narración. $\mathrm{O}$ bien optar por una determinada caligrafía, general, invariable, que ofrece aspectos descriptivos, define el tono de la historia o el carácter de un personaje en toda la obra. Y lo hace visualmente.

La FIG. 6 y la FIG. 7 son pertinentes para comprender la capacidad expresiva que con una grafía determinada se puede otorgar a un momento puntual de la historia narrada. Se trata de dos viñetas de una misma escena de Astérix legionario, de René Goscinny (1926 - 1977) y Albert Uderzo (1927), que expresan dos estados anímicos de un mismo personaje. La primera imagen muestra, en la persona de un centurión romano, un momento de iracundia. No solo mediante un expresivo dibujo y el coloreado de su rostro encendido, sino porque las palabras que pronuncia, dentro de su correspondiente globo de texto, son de trazo anguloso, duro, cargado de aristas, y evidentemente de un tamaño enorme en comparación con las frases de su contertulio (y con la onomatopeya que expresa un cornetín sonando fuera de campo, que adquiere tintes cómicos). Se diría que las letras de ese expresivo “¡cállateee!” cortan el espacio, lo invaden con agresiva vehemencia.

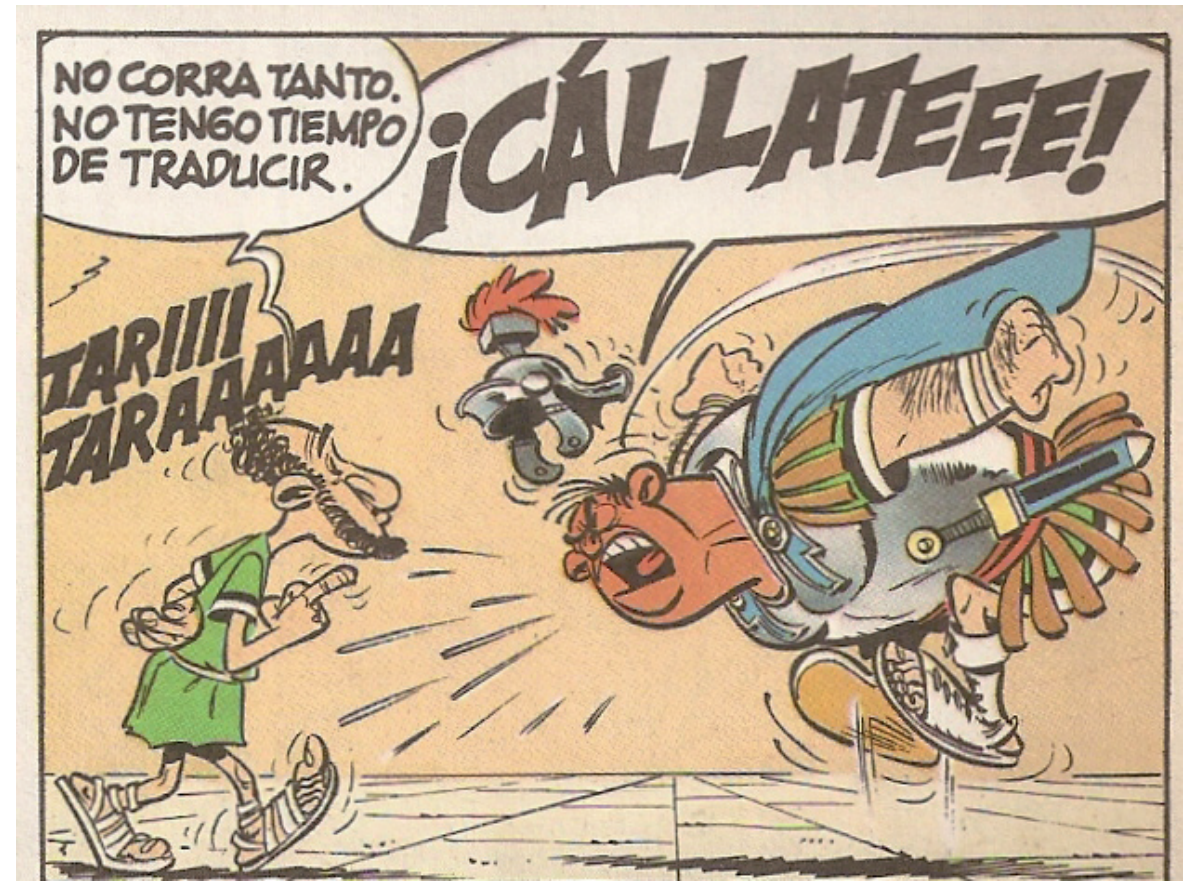

FIG. 6. Astérix legionario, René Goscinny y Albert Uderzo, 1966. 
Sin embargo, pocas viñetas después, y víctima de un pelotón de reclutas anárquico y desobediente liderado por el galo Astérix y su compañero Obelix, el mismo individuo estalla en un sonoro llanto. Nuevamente el dibujo y la forma son elementos de la narración y proponen contenido en la grafía: de gran tamaño aún, pero su trazo se torna ahora tembloroso, roto, como si el pulso al rotular hubiese fallado. Además vemos cómo el llanto aumenta su tamaño letra a letra. La desesperación, finalmente, ha rendido $\mathrm{y}$ vencido al autoritario personaje.

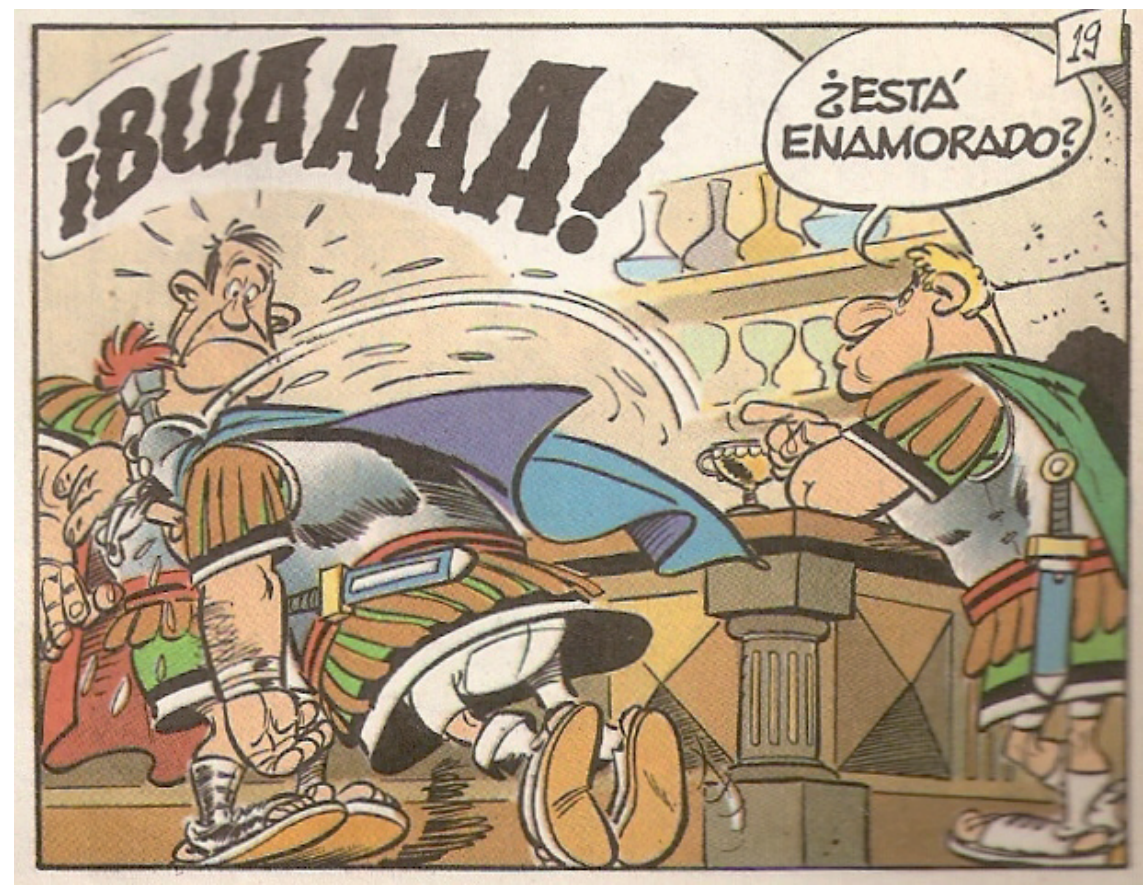

FIG. 6. Astérix legionario, René Goscinny y Albert Uderzo, 1966.

Este ejemplo de dos momentos prácticamente contiguos y donde se dibujan dos grafías tan diferentes evidencia la propiedad narrativa de la letra como signo icónico, la facultad expresiva de determinadas elecciones gráficas a la hora de atender al texto escrito en el cómic. Comprobamos pues que el autor de historietas posee un verdadero abanico de posibilidades, y que desde lo meramente visual aplicado a la escritura puede controlar las variaciones de su narración. Del mismo modo que una letra angulosa transmite determinados estados de ánimo, una de aspecto orgánico, o contornos suaves y redondeados, pueden precisarse para describir situaciones opuestas (de relax, o de estado alterado de conciencia, por ejemplo). Y además, para narrar todo cuenta: el tamaño de la fuente escrita, si este tamaño permanece estable o varía silábicamente o letra a letra produciendo la sensación de un volumen fluctuante, incluso el tono cromático aplicado a la oración escrita. El campo es tan amplio como la imaginación del rotulista aplicado a su oficio.

Pero como hemos apuntado, existe otra posibilidad más allá de la capacidad de variar puntualmente una línea de texto determinada en aras de encontrar un efecto narrativo. En ocasiones los autores crean una caligrafía específica y personalizada, bien para los diálogos de un personaje, bien para los textos de apoyo o para los títulos de una obra. Atendiendo al primer caso, veremos que efectivamente se puede perfilar una definición psicológica sin necesidad de otros elementos que no sean la manera de escribir los parlamentos de un personaje.

Acudimos para reflejar esta propiedad a la FIG. 8, perteneciente a la obra Batman, Arkham Asylum, de Grant Morrison (1960) y Dave McKean (1963). Este cómic supone la inmersión de Batman en una pesadilla gótica. El sanatorio mental donde los enemigos del hombre murciélago son internados tras su derrota sufre una rebelión de los trastornados villanos, que toman a sus funcionarios de rehenes y obligan al superhéroe a internarse en las oscuras profundidades del manicomio. Un relato turbador sobre todo por las imágenes pictóricas de Dave McKean, que describen plásticamente, con técnicas mixtas y collages abundantes, el estado pesadillesco del entorno. 
Y el ilustrador se recrea no solo en las texturas pictóricas de raíz expresionista y con numerosos guiños al expresionismo abstracto sino que cuida enormemente la entidad de la letra elegida. La rotulación (a cargo de Gaspar Saladino, quien comenzó a trabajar para DC Comics en los años sesenta) dota a cada personaje de su propia caligrafía, sus diálogos reciben forma, color y una presencia visual diferenciada y, sobre todo, plena de información visual. En este sentido si Batman se define con unos globos negros sobre los que se escribe letra blanca, expresando un mundo interior frío y atormentado, su rival el Joker, el payaso loco y asesino, se expresa libre de globos de texto y con una grafía volumétrica, de explícito color rojo con bordes blancuzcos, y de trazo irregular, con frases sinuosas, símbolo todo ello del espíritu anárquico, desquiciado y amoral del personaje.

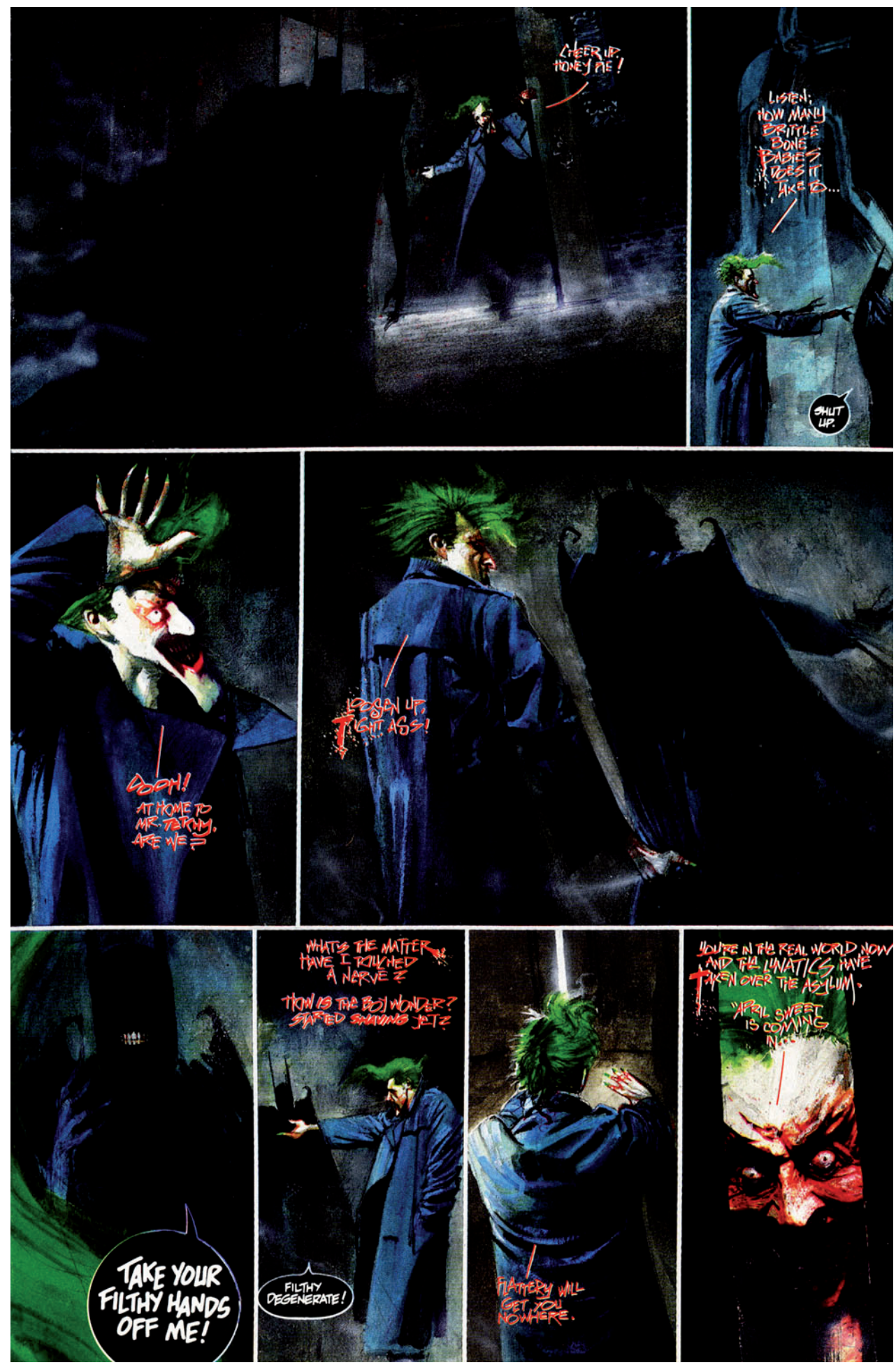

FIG. 8. Batman, Arkham Asylum, Grant Morrison y Dave McKean, 1989. 
Vemos así cómo sin más elementos que los visuales los autores pueden, atendiendo a la caligrafía vinculada al personaje en sus diálogos, transmitir información sobre el mismo, describiendo sus caracteres sin precisar para ello de más elementos aunque evidentemente el curso de la acción determinará y definirá a sus protagonistas.

La escritura como trazo, como dibujo en sí misma, tiene una funcionalidad y puede aportar narración, contenido contextual y caracterización. En este último aspecto, además, no hay que restringirse solo a la posibilidad de perfilar con la rotulación a un determinado personaje de la ficción, ya que también se puede definir mediante el tipo de caligrafía el tono en la narración. Incluso ilustrar el género específico en que se enmarca un relato historietístico.

Puestos a identificar un género narrativo mediante una determinada fuente escrita, posiblemente lo más agradecido sea ejemplificarlo con una obra inserta en el modelo del terror (al que por cierto en el fondo pertenece nuestro anterior ejemplo, ese Batman de pesadilla, donde la grafía ciertamente ya da pistas sobre ello). La FIG. 9 corresponde a una adaptación de una obra de Lovecraft por parte del argentino Alberto Breccia (1919 - 1993) con la ayuda literaria de Norberto Buscaglia (1945).

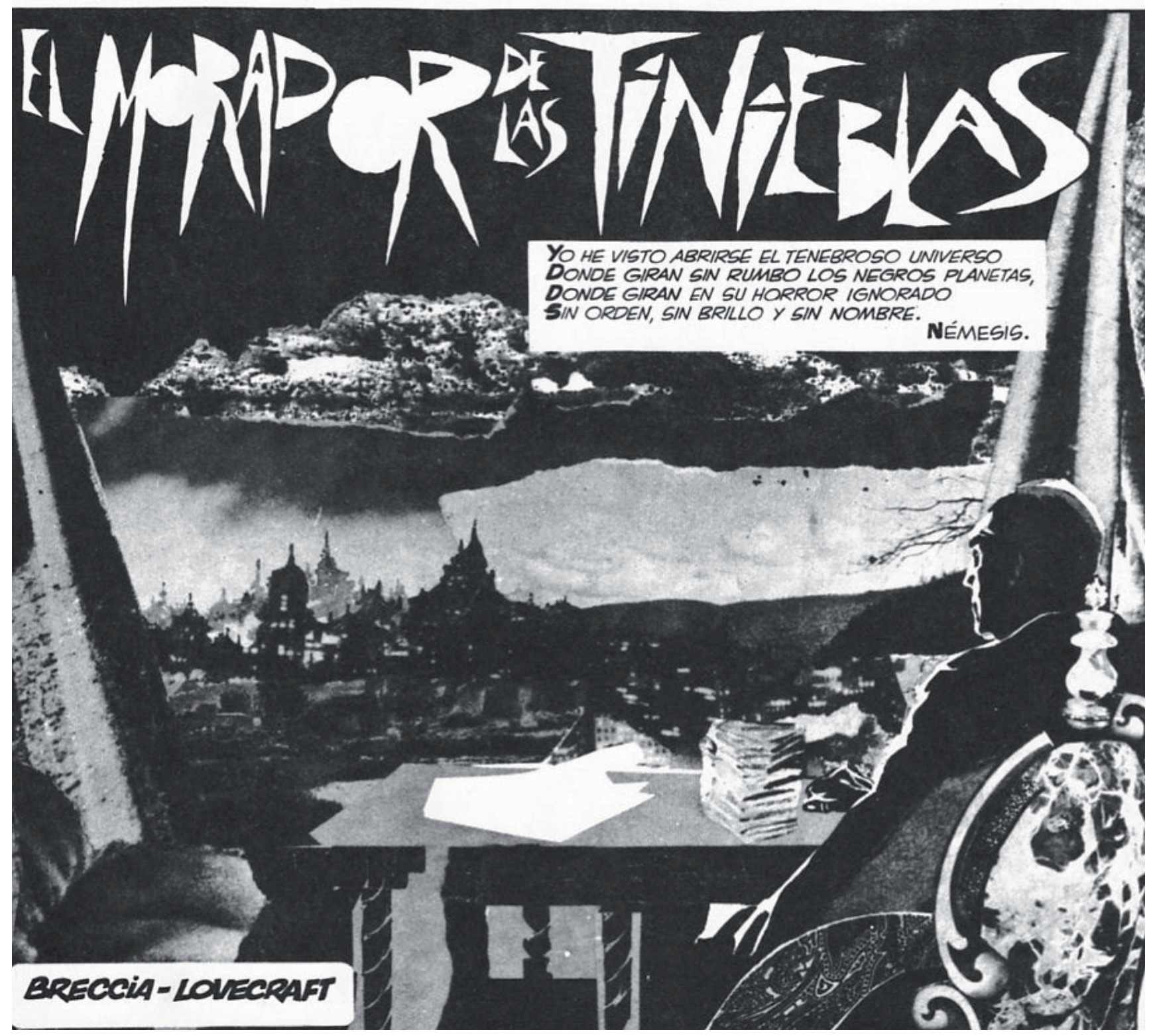

FIG 9. El terror de las tinieblas, Norberto Buscaglia y Alberto Breccia, 1973. 
Aunque las cartelas no recurren a una letra especialmente indicativa, sí cabe pararse en el título, "E1 morador de las tinieblas". La combinación de su grafía con la imagen ya es ominosa: Breccia ilustra con un estilo plástico, pictórico y levemente abstracto, un hombre sentado ante su ventanal que observa el paisaje. Una ciudad hace de horizonte y sobre un cielo tormentoso (¿० son abruptas montañas?) se extiende la negrura más pura. Y en este espacio se incrustan las letras hirientemente blancas y de caligrafía muy informativa que hereda los modos de una tradición que proviene del cine: los títulos de horror de la Hammer y aún anteriores, como los de los estudios Universal, son acervo cultural del género del terror. También la industria del comic-book tiene su tradición en el terror ${ }^{1}$ así como la literatura pulp y otras ramificaciones culturales vinculadas al género. Con este contexto cultural es fácil advertir que la forma de la letra tiene en Breccia un papel informativo nítido, nos ubica en un estado de ánimo como lectores que remite, directamente, a lo misterioso y lo aterrador. Una vez más, mediante una bien planificada función de lo visual empleada en lo caligráfico.

Por supuesto, cada género narrativo podrá ser más o menos receptivo a esa identificación con una determinada grafía. Un tipo de letra puede sugerirnos terror, comedia, quizá ciencia ficción. Más difícilmente costumbrismo... pero ello no dependerá de la capacidad de la fuente escrita y sus propiedades icónicas, sino del talento autoral, evidentemente, que en última instancia es el que enriquece el medio con su capacidad y oficio.

\section{LA LETRA COMO EXPRESIÓN ESPACIAL Y TEMPORAL EN LA HISTORIETA.}

Dado que en numerosas ocasiones con la letra se está creando una manifestación sonora en la narración, esta no deja de ser un evento que sucede en un determinado tiempo y un espacio concreto. No siempre es así, claro. En este sentido hay que distinguir entre dos modos diferenciables. Por un lado están los discursos de un narrador, siendo el más usual la tercera persona omnisciente, vinculados en historieta a los cartuchos por norma general, donde se procede a la descripción y narración de los acontecimientos. Carecen estos textos de una naturaleza diegética dentro de la historia. Y por otro lado contamos con onomatopeyas y líneas de diálogo, que deben interpretarse como sonidos dentro de la ficción, con lo que se imbuyen de ciertas propiedades que son aquellas que a continuación atendemos. $^{2}$

La grafía en el cómic, en este sentido, puede exponer tanto un intervalo de tiempo dentro de la acción como expresar un movimiento físico, un recorrido. O incluso ser información focal, remarcando un lugar concreto. En la FIG. 10 comprendemos la primera de estas cualidades en una viñeta de Les Manufacturées de Georges Pichard (1920-2003) y Carmen Faraldo.

Si la escena se nos brindara sin diálogo ni onomatopeya, la estampa sería prácticamente inerte, estática. Un primerísimo plano de un pie a la izquierda, un niño, tres diminutas muchachas sobre motocicletas. El globo de texto sin embargo ya supone una indicación temporal. La línea de diálogo expresa una dicción, lo que implica obviamente un hiato temporal aunque sea de pocos segundos. Pero más aún que a

\footnotetext{
1 Destacan los cómics de terror de la editorial EC Comics, que explotaron lo truculento en la década de los cincuenta del pasado siglo, y a su éxito se subieron muchas otras editoriales que hicieron del horror el género dominante, hasta la irrupción de los códigos morales y las autocensuras del gremio editorial norteamericano en esa misma década.

2 Hay un tercer vértice, a medio camino de la narración descriptiva no diegética que supone la voz de un narrador en las cartelas, y de los diálogos y sonidos que se producen en la ficción relatada: los globos de pensamiento. Estos pueden someterse, por mero ejercicio literario, a un estilo verista, expresando pensamientos literales que, por así decirlo, suceden en la acción (monólogo interior). Pero también existen muchos ejemplos donde las líneas de cavilación son textos muy articulados, más elaborados, y por tanto un ejercicio literario que no pretende simplemente plasmar un pensamiento en un momento, lugar y tiempo reales dentro de la acción. Para ahondar en este concepto, leer las reflexiones al respecto de Gerardo Vilches en su blog divulgativo "The watcher and the tower", en el artículo "Lecciones de tebeo VII: El Globo de Pensamiento" (http://thewatcherblog.wordpress.com/2011/10/13/lecciones-de-tebeo-vii-el-globode-pensamiento/).
} 


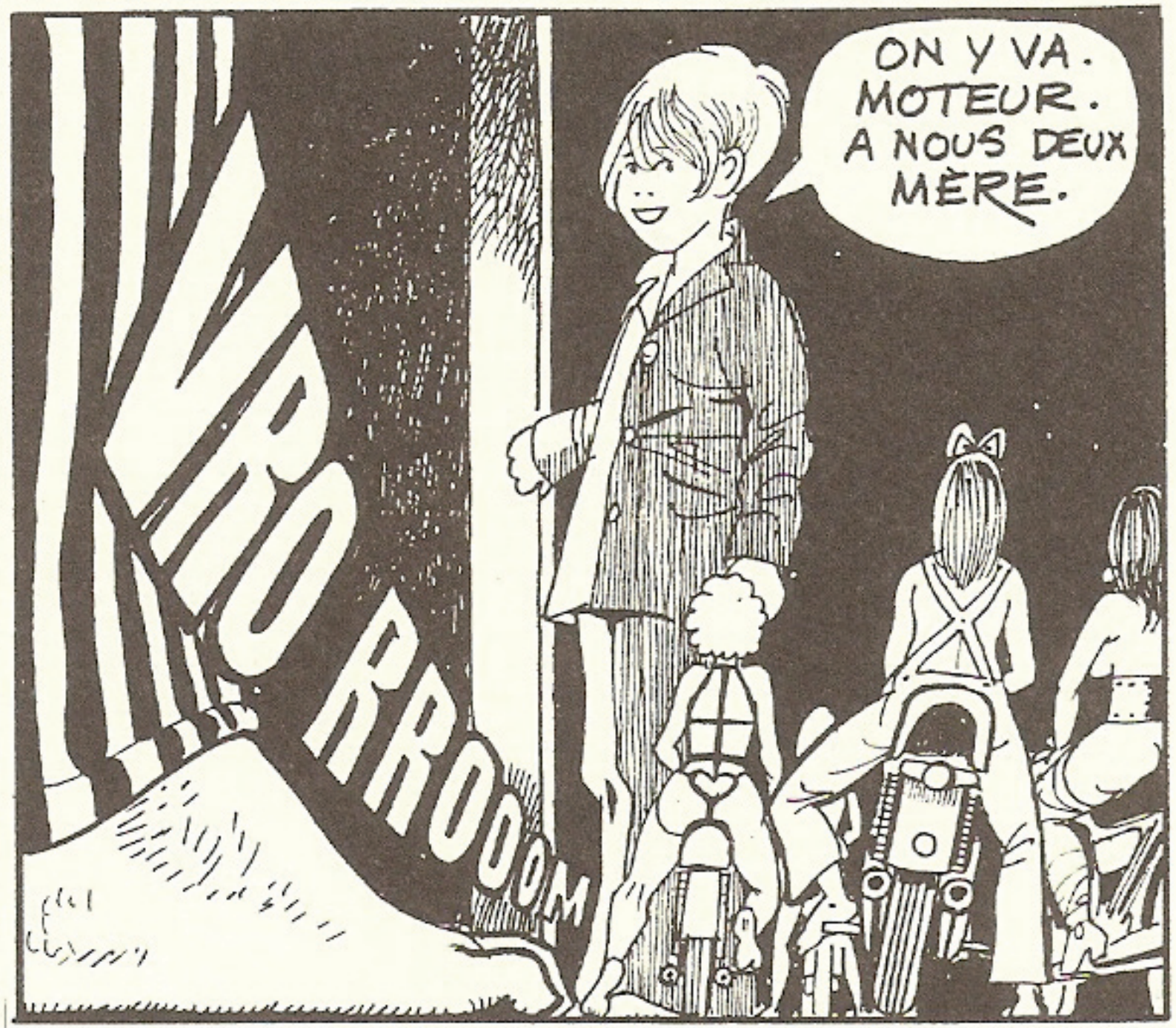

FIG. 10. Les Manufacturées, Carmen Faraldo y Georges Pichard, 1972.

ese texto quiero atender a la onomatopeya. Si la frase pronunciada sugiere un intervalo más o menos impreciso ya que el texto puede ser recitado con más velocidad o con más parsimonia, evidentemente el sonido de una aceleración en un ciclomotor no ofrece dudas y el lector entiende que dicho rugido mecánico se extiende por un tiempo de pocos segundos. Nadie podrá acotar si la escena dura tres, cinco u ocho segundos, pero cualquier lector comprende que ni es un instante ni tampoco, por ejemplo, cuestión de minutos.

Entender la letra escrita en esta vertiente de medida de tiempo más o menos flexible ofrece una rica gama de posibilidades para el autor. La grafía puede ser un elemento de la narración que permite un eficaz control del tiempo de lectura (el ritmo de la lectura que nos impone la propia obra). La FIG. 11 es un extracto de El corazón delator, versión del relato de Edgard Alan Poe por parte de Alberto Breccia. Un cuento donde un asesino esconde a su víctima pero, en presencia de la policía, comienza a escuchar los latidos del difunto, cada vez más fuertes, hasta que desesperado, confiesa y se entrega. Cuento de enajenación, angustia y tensión psicológica que Breccia orquesta en un juego de imágenes repetidas donde las onomatopeyas ostentan un papel fundamental. El "TUMP” se manifiesta en viñetas alternas creando un compás rítmico, que nos sugiere un "tempo" natural de breves segundos entre cada intervalo pues son, supuestamente, los latidos de un hombre. Pero al tiempo crean una tensión narrativa que dilata ese cronómetro natural en una espera emocionalmente interminable. 

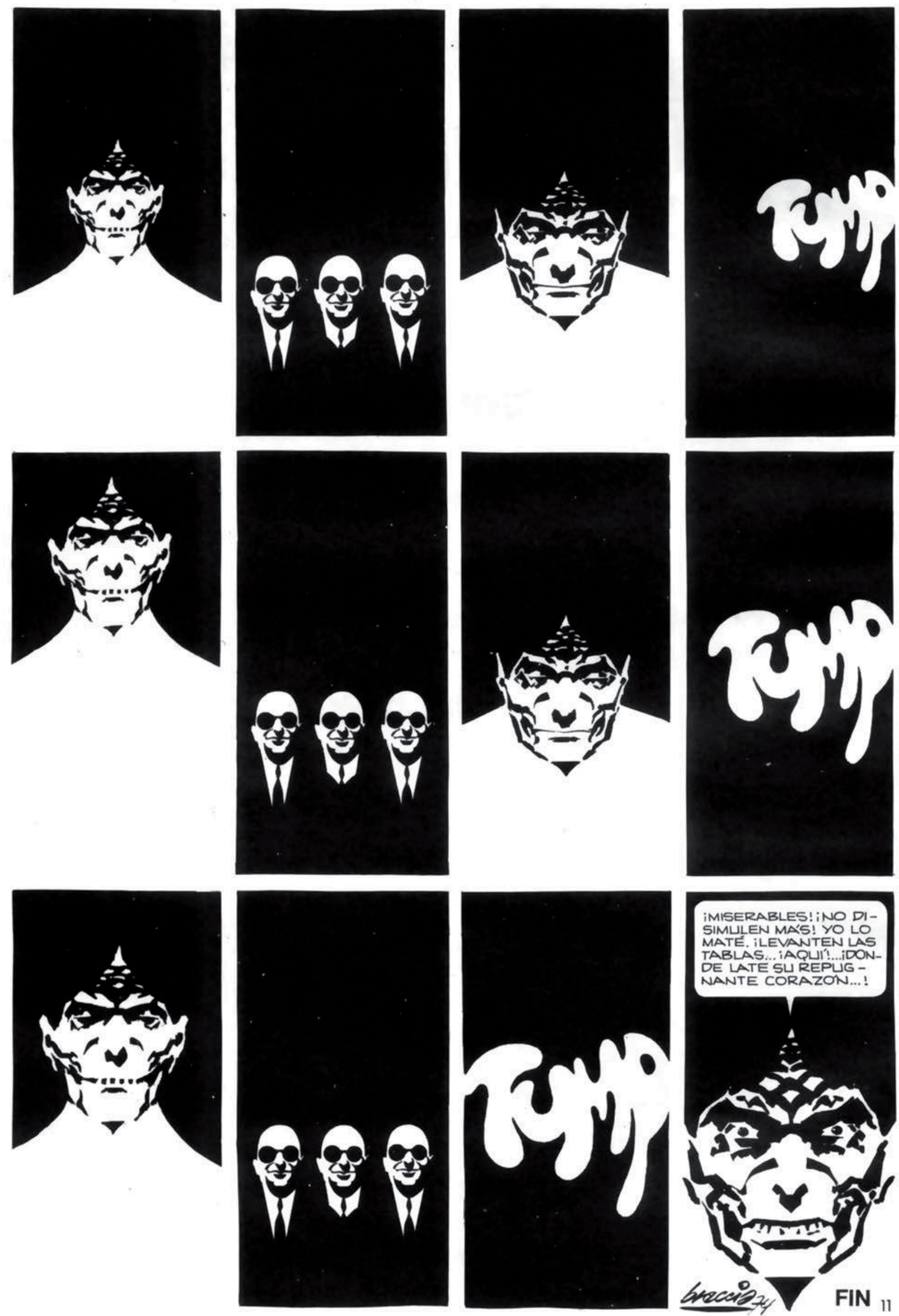

FIG. 11. El corazón delator, Alberto Breccia, 1975. 
Evidentemente vemos también el empleo de recursos ya analizados, como la forma de dibujar esas onomatopeyas, el contraste blanco / negro o el tamaño cada vez mayor, viñeta a viñeta, de la representación del latir. El dominio del tiempo narrativo y de los recursos expresivos del dibujo de la letra escrita nos brindan aquí un ejemplo de refinamiento formal clarísimo, que corrobora en doce viñetas muchas de las teorías vertidas ya en este estudio.

Pero volvamos a los diálogos, líneas de texto que formulan, dentro del cómic, aquello que los personajes dibujados hablan. Como hemos explicado, con ellos se articulan intervalos temporales. Es una idea que rompe con la de que es la viñeta la unidad de expresión mínima de la historieta, pues sin ir más lejos, en el seno de ese espacio podemos encontrar subdivisiones de entidad narrativa, y esas atomizaciones de la viñeta pueden, en ocasiones, deberse a los textos de la misma. ${ }^{3}$

La FIG. 12 pertenece a Robert Crumb (1943). En ella el que está considerado uno de los autores más importantes del cómic contemporáneo se retrata ante un periodista que está entrevistándolo. Gary Groth, concretamente, director de la revista especializada The Comics Journal.

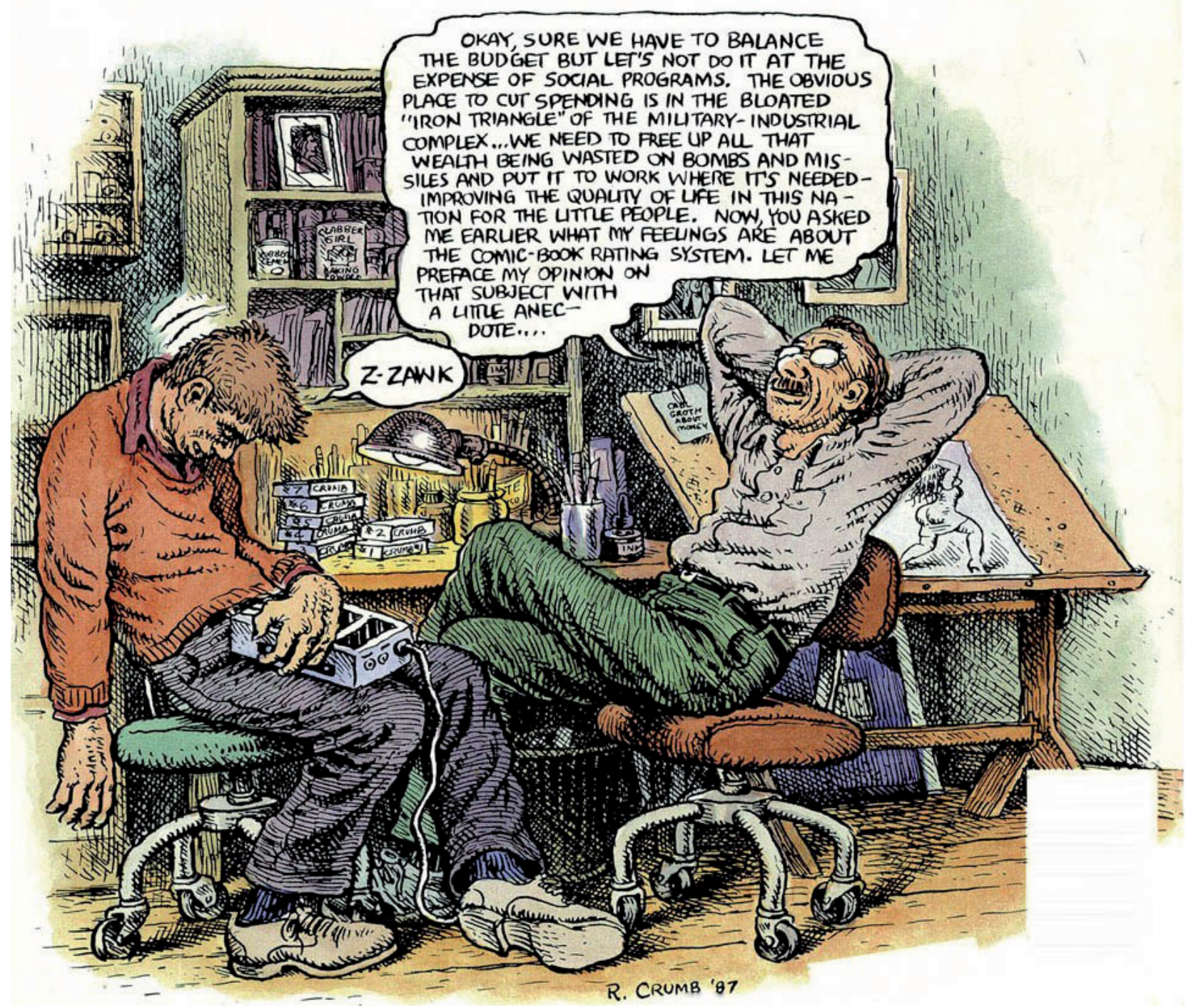

FIG. 12. Ilustración de Robert Crumb para la portada de The

Comics Journal n. ${ }^{0} 121,1988$.

\footnotetext{
${ }^{3}$ No queremos abundar en un concepto que escapa a nuestro estudio, pero cabe denotar que ya hemos visto ejemplos que defienden esta idea. En la FIG. 3, donde Krazy Kat es agredida por el ratón Ignatz, encontramos como mínimo dos significados menores que el total de la viñeta: uno, el lanzamiento del ladrillo por el ratón, y otro el éxito del mismo concluyendo en golpe certero sobre el cogote de Krazy.
} 
Nuevamente la imagen, como en el caso de la FIG. 10, podría ser una estampa estática, una captación de un instante o una representación simbólica, como si estuviésemos ante una ilustración decimonónica. Dos líneas de diálogo, sin embargo, consiguen dotar al cuadro de narratividad e incluso sostienen la comicidad de la escena ilustrada. Porque es evidente contemplando el diálogo que el generoso párrafo saturado de autoindulgencia que el autor otorga a su alter ego contrasta con el breve ronquido de su supuesto interlocutor. La longitud del monólogo (incluso física, pues ocupa, como dibujo, un espacio casi mayor que la librería del fondo) y la naturaleza gramatical de las frases de Crumb, rebuscadas, recargadas, nos ofrecen un discurso de tipo temporal: la perorata se extiende en el tiempo hasta el aburrimiento. Y si el tiempo pasa y el dibujante habla y habla sin parar, el dormido reportero no extiende su ronquido más allá de una porción de segundo, breve, concisa. Su "z-zawk", que podemos leer como un respingo, contrasta cómicamente con aquel dilatado soliloquio.

Es evidente a la luz de los ejemplos que con lo que se escribe en la historieta se da una forma de expresión y descripción de transcurso del tiempo, tal como enseñan la ilustración de Robert Crumb y ejemplos anteriores, pero también la grafía puede ser utilizada para describir icónicamente un movimiento físico, un desplazamiento dentro de la ficción. La FIG 13, viñeta de Los inoxidables, del guionista Víctor Mora (1931) y el dibujante Antonio Parras (1929-2010), ilustra la caída al vacío de un elevador mediante el desesperado grito de su pasajero.

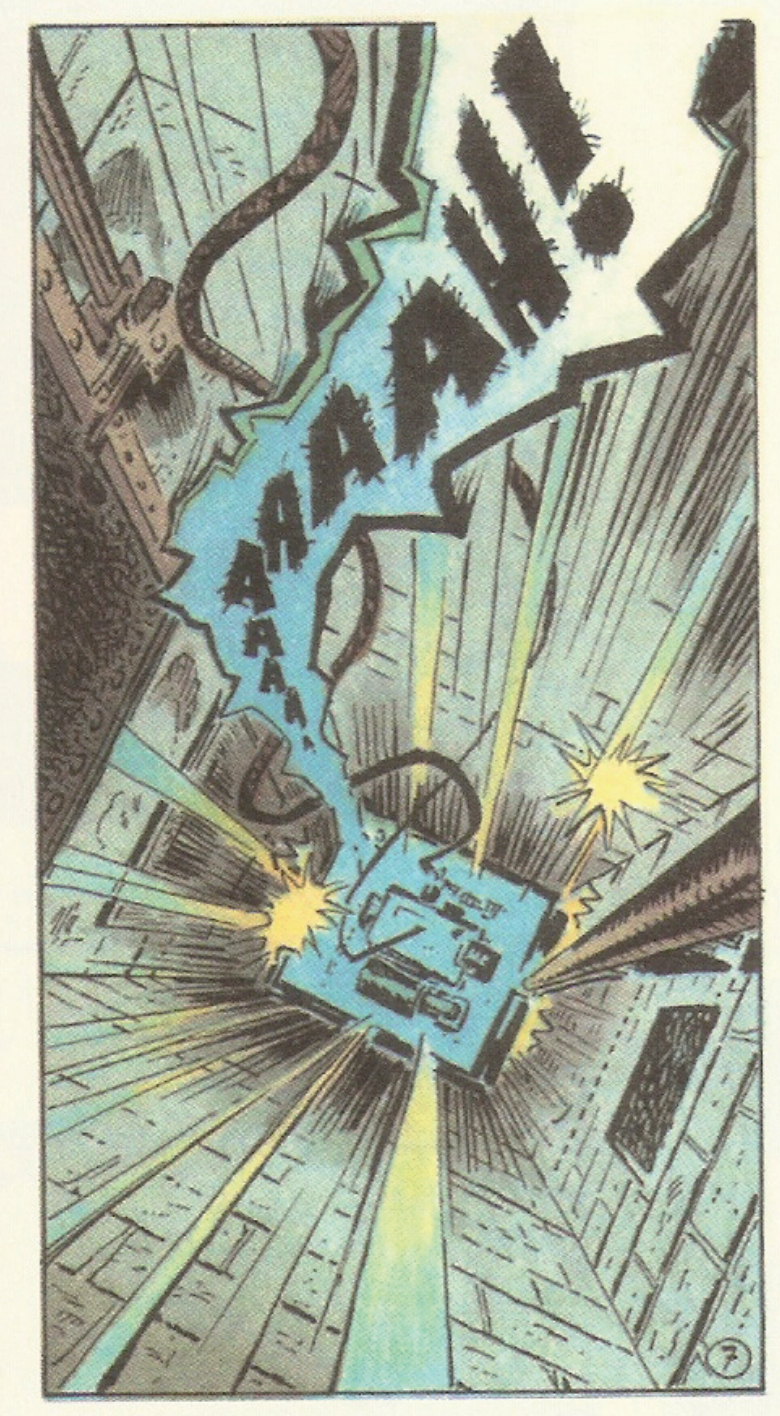

FIG. 13. Los Inoxidables, Antonio Parras y Víctor Mora, 1982. 
Al margen de que aquí podríamos analizar más propiedades narrativas de la onomatopeya, la verticalidad de la misma dibuja el camino realizado, y la variación de la fuente, decreciente, indica alejamiento desde el punto de vista del lector. Por decirlo de un modo ilustrativo, el espectador de la escena la contempla sin acompañar la caída, y al alejarse el ascensor, la letra nos indica ese alejamiento en desplome.

Vemos así que no es asimilable el concepto de simple caligrafía (que según el Diccionario de la Lengua de la Real Academia Española sería el conjunto de rasgos que caracterizan la escritura de una persona, de un documento, etcétera) con el más extenso del dibujo de la grafía que aplico a la historieta, donde más allá de la forma caligráfica de las letras se atiende a aspectos como su disposición en el espacio, su tamaño, la fluctuación del mismo, el color o colores de lo escrito... recursos que aportan información, como en el caso de la figura analizada, donde nos relata una caída, o en el siguiente, la FIG. 14, de Calvin y Hobbes, obra de Bill Watterson (1958).

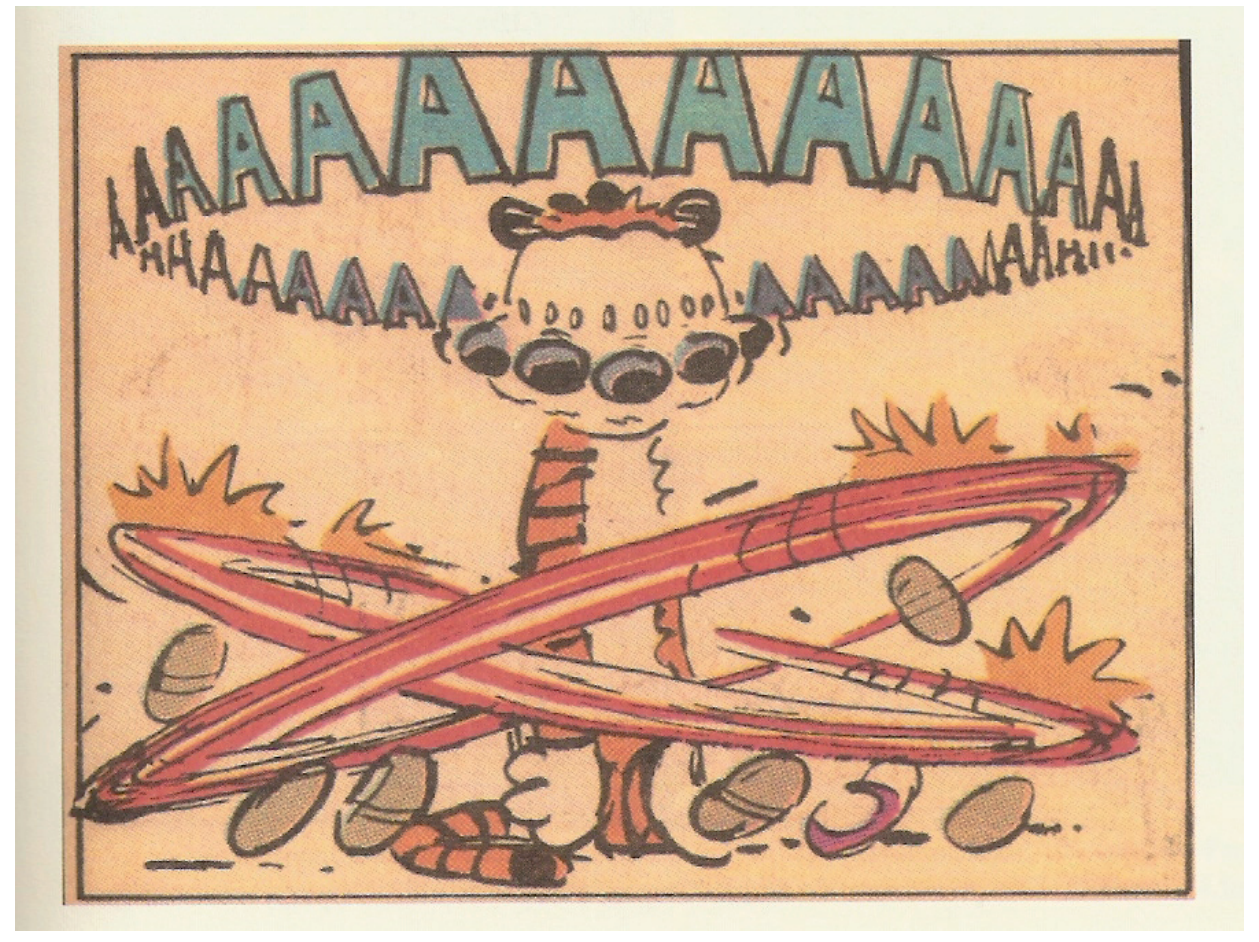

FIG. 14: Calvin y Hobbes, Bill Watterson, 1985.

Porque en la viñeta del niño corriendo alrededor del tigre (real solo en la imaginación de Calvin, pues Hobbes se trata de un peluche) el dibujo del grito del crío es todo él pura narración de una acción física. Lo es, por descontado, por cómo está dibujado envolviendo al felino en una elipse, habitual icono de traslación. Lo es también por cómo el tamaño de la letra "A" aumenta o disminuye según su ubicación en el espacio de la acción. Incluso es ocultado parcialmente por el de otros fonemas para sugerir gráficamente la carrera del niño alrededor del muñeco. Y es más, la onomatopeya expresa acercamiento o alejamiento a la "cuarta pared" virando su tomo cromático. Este ejemplo, por todo ello, aglutina los dos aspectos que hemos analizado, pues insinúa siquiera con vaguedad un tiempo transcurrido, o cuanto menos una acción, y define el movimiento físico de los personajes.

Por último hay que retomar un concepto ya mencionado en la FIG. 6, la plasmación del sonido en fuera de campo, que indica la procedencia física de unos hechos, sean un diálogo o una acción que el autor nos escatima en la ilustración de la viñeta. Del mismo modo que el cine emplea el sonido en off de un modo dramático, cómico o meramente narrativo, el cómic puede usar la letra escrita con semejante intención, ofreciendo el espacio en off un juego narrativo con aquel otro que sí es mostrado en la viñeta o secuencia de viñetas. Esta interacción entre lo que se muestra y lo que no vemos puede venir de la mano de la letra escrita. Es interesante al respecto la FIG. 15, en la que volvemos al Thimble Theatre de Segar. 

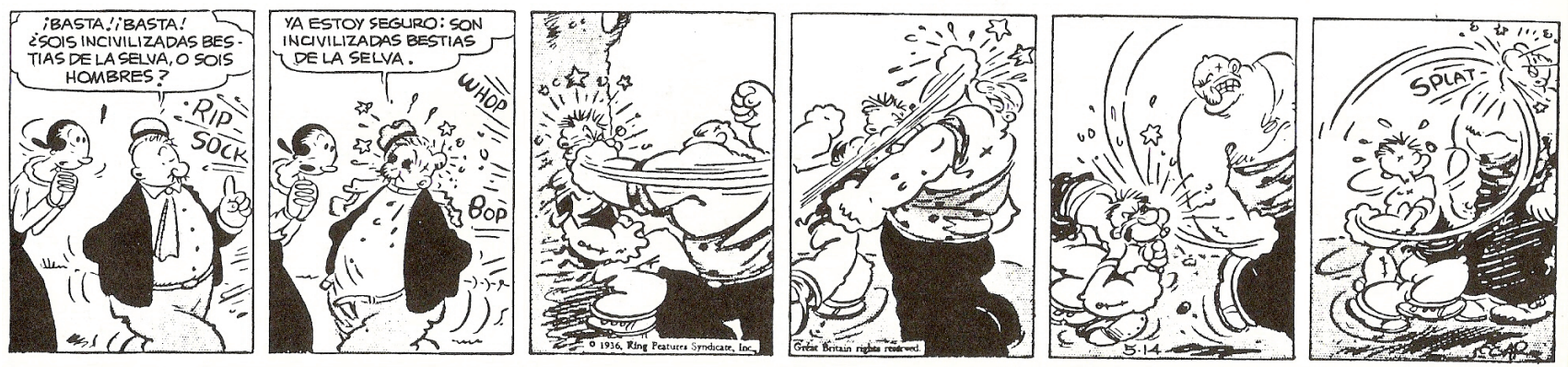

FIG. 15. Thimble Theatre, EC Segar, 1936.

En esta tira diaria vemos en sus dos primeras viñetas unas expresivas onomatopeyas que describen la acción principal, en off visual: Popeye y otro individuo están enzarzados en una pelea, que es observada por su novia Olive y su amigo Pilón. Este último entra a mediar entre ambos y sale apaleado en la segunda viñeta. O mejor sería decir "sale" a mediar y "vuelve" apaleado. Las siguientes viñetas de la tira nos trasladan a lo que hasta entonces era un espacio sugerido por la onomatopeya. El autor, ahora que sí representa el centro real de la acción, prácticamente no emplea las onomatopeyas. El recurso de la escritura ha servido para narrar lo que no era visible, en dónde sucedía (margen derecho de las viñetas iniciales) y para, mediante esa descripción de lo que no podemos ver en la escena, crear un momento de comicidad gracias a una inteligente elipsis entre la primera y la segunda viñeta. Cuando dichos hechos son representados en las siguientes viñetas lo textual ya no tiene objeto, pues podemos ver en toda su crudeza el baile de mamporros.

Otro uso de la grafía en tanto que indicativa de un determinado lugar sería, frente al fuera de campo que acabamos de analizar, la de ser, por su forma y ubicación, un elemento de información focal. Es bastante ilustrativo en este sentido el empleo gráfico que los autores otorgan a la onomatopeya cuando esta señala un impacto. La FIG. 16 corresponde a Spiderman nuevamente, de Stan Lee (1922), Gerry Conway y el ilustrador John Romita. En ella una techumbre se desploma sobre la gente, y los esfuerzos del héroe no han podido impedirlo. El impacto se refleja con una onomatopeya partícipe de no pocas características ya estudiadas, pero ahora señalaremos una más. Su disposición como elemento dentro de la viñeta no es aleatoria, sino que transmite esa información localizadora, apuntando el lugar físico del propio impacto.

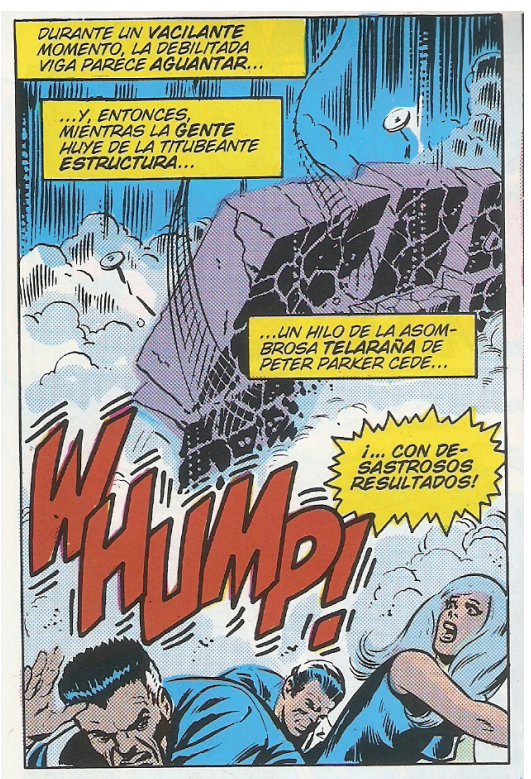

FIG. 16. Amazing Spiderman vol. 1, n. ${ }^{\circ}$ 117, Stan Lee, Gerry Conway y John Romita, 1973. 
Pero en ocasiones la onomatopeya no pretende la focalización. Es más, llega a trascender cualquier punto concreto dentro de la acción y se produce un empleo de la letra ciertamente original: más allá de ocupar un lugar preciso en la viñeta, la letra escrita sería el marco para la imagen dibujada, haciendo por tanto la función de viñeta. Es la letra como viñeta contenedora, una forma de subordinar el todo que ilustra esa escena a la letra escrita que define esa acción, otorgándole una importancia absoluta, tanto descriptiva como simbólica. Un recurso para la narración que añade connotaciones expresivas: drama, intensidad, matices humorísticos a la escena, etcétera. La FIG. 17 pertenece a Sin City, de Frank Miller. Esta serie noir y visceral trata sobre una ciudad corrupta y feroz, llena de criminales, violencia extrema e idealismo en bruto. Los héroes de la Ciudad del Pecado son tan violentos como los criminales y defienden un ideal del bien absoluto y sin medias tintas. En la página de ejemplo el protagonista, esto es, el hombre justo, asesina fríamente a un vicario de una iglesia corrompida y amoral. El drama, mezclado con un estallido de violencia tras una escena casi reposada en las anteriores páginas (todo ocurre dentro de un confesionario, en una iglesia) se acentúa con el empleo de la onomatopeya como marco de las tres primeras viñetas. La calma vuelve a sugerirse, por contraste, retomando en la última de ellas la forma rectangular, más usual. El crimen se ha cometido. La justicia se ha cumplido. El héroe, pese al asesinato brutal que acaba de cometer, está en paz. Y si el crimen es brutal, decíamos, lo es por el enfático efecto de las viñetasonomatopeya. En ese intervalo de tres disparos todo el universo formal se encierra en el hecho concreto del acto de disparar, de matar. Las tres onomatopeyas, además, encierran ilustraciones tan icónicas como simbólicas: un primerísimo plano del arma en contraluz, el cráneo del sacerdote reventando por la balacera, también en claroscuro, y finalmente un crucifijo que, por así decirlo, se ha virado: el contraluz está invertido, el cuerpo opaco del signo religioso se dibuja en blanco sobre un fondo negro.

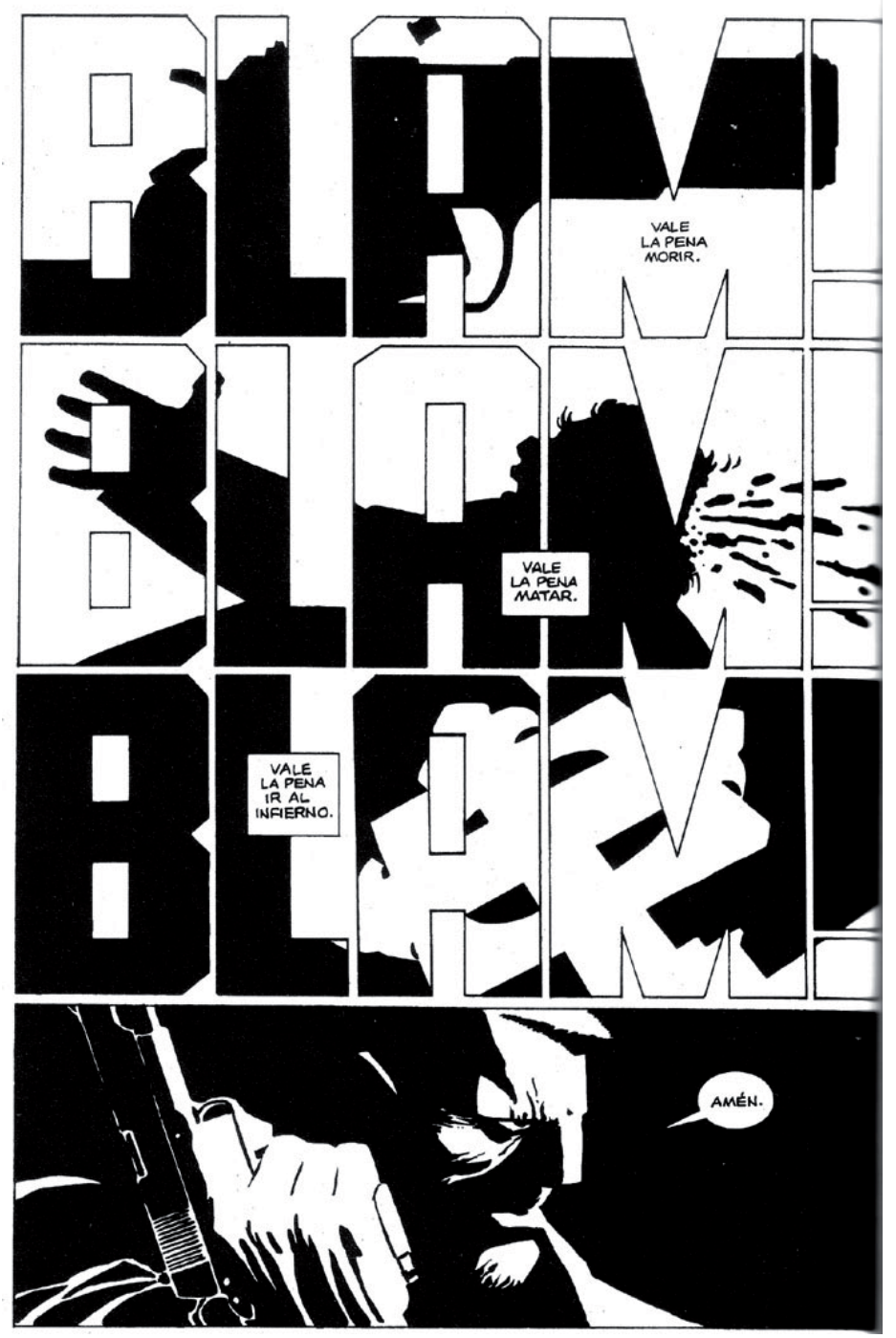

FIG. 17. Sin City, Frank Miller, 1991. 
La cuarta imagen, como hemos dicho, vuelve a una representación más común de viñeta rectangular, y contiene un dibujo menos simbólico, más naturalista dentro de los parámetros de una obra poco naturalista y que fuerza continuamente los altísimos contrastes de luces y sombras.

El de Sin City es un buen ejemplo, en fin, de cómo la onomatopeya, tomando las funciones de la viñetamarco de la representación, añade información narrativa a lo contado, más allá de los hechos ilustrados y descritos o del significado de todo lo escrito en la secuencia, con lo que el efecto por supuesto interactúa para crear un todo informativo.

\section{Epílogo: El ELEMENTo TEXTUAL EN EL PANORAMA DEL Cómic CONTEMPORÁNEO.}

En el cambio de siglo Xx a XXI varias han sido las dinámicas que han caracterizado a la evolución de la historieta. En un mundo cada vez más interconectado a golpe de un clic los movimientos o escuelas historietísticas han recorrido caminos paralelos casi independientemente de localizaciones geográficas. Vivimos, en definitiva, un mundo globalizado (al menos un Primer Mundo globalizado) y, en cómics, un panorama muy dividido y por ello cada vez más plural. Los tebeos de superhéroes se han convertido mayormente en un engranaje en un mecano de franquicias mucho más golosas (el cine, los videojuegos, los juguetes) y la historieta más personal, bajo el influjo de precedentes como Robert Crumb, Art Spiegelman o los hermanos Jaime y Beto Hernandez, en su aspiración por llevar al autor al primer plano, ha influido en el panorama europeo. ${ }^{4}$ Este también, en los últimos lustros, ha visto cómo crece ese cómic de intenciones artísticas mientras las fórmulas más comerciales se estancan (no en ventas, pero sí en creatividad). Y Japón es todo un universo editorial que también se permea y penetra en mercados occidentales, por descontado.

En esta instantánea inevitablemente reduccionista hay que asentar el movimiento más controvertido y al tiempo apasionante de los últimos tiempos. A partir del cómic alternativo y de las propuestas más autorales del mercado francés con el movimiento que se dio en llamar nouvelle $B D$, desde finales del siglo $\mathrm{xx}$ se ha establecido una realidad a medio camino del movimiento artístico y el formato de impresión: la novela gráfica. Un montante de autores que, libres de parámetros impuestos por el mercado o las editoriales, simplemente crean obras no sujetas a continuidades estrictas, un número de páginas marcado de antemano, un determinado estilo gráfico, un tema concreto o un tamaño de hoja. Y que se está asociando a un cómic adulto por temática y ambición, sea cual sea la noción estética de sus planteamientos gráficos y sus modos de narrar secuencialmente. Hoy se da una conciencia autoral y generacional, una hornada de autores que siente que puede trabajar con esa libertad, un grupo tan heterogéneo estilísticamente como cohesionado por esa conciencia de autor, que trabaja en un panorama industrial determinado. Uno mucho más permeable que antaño a sus deseos respecto al resultado final de su obra en todos los aspectos que le atañen (estilo gráfico, tema, tamaño y volumen del libro, apariencia, etcétera). En el marco de un formato, el de libro, que ha permitido la visibilidad del cómic en nuevos lectores, gracias a su distribución ya no solo en librerías especializadas sino en puntos de venta más generalistas.

Y además, desde esa supuesta libertad los autores se definen antes artistas que artesanos. En este contexto no es infrecuente que el apartado gráfico de los dibujantes de novelas gráficas carezca en apariencia, superficialmente, de la vistosidad y el detenimiento del modelo autoral de hace veinte años (o simplemente del de otro tipo de cómic igualmente válido, pero diferente). En los creadores de discurso más maduro y artístico del siglo xxi observamos, en consonancia con este principio, un grafismo que no es sensorial sino conceptual. No le interesa el virtuosismo por el virtuosismo (es más, suele eludir los modelos naturalistas que imperaron, por ejemplo, en la tradición francobelga). Sus virtudes derivan de un análisis profundo o al menos detenido de sus obras.

\footnotetext{
${ }^{4}$ Influjo al que cabe sumar, indudablemente, la propia tradición del cómic del viejo continente, sobre todo el franco-belga con notables ejemplos del avance desde una historieta "para todas las edades" al compromiso estético y argumental de una historieta "de autor", para lectores adultos, rastreable ya en los lejanos años sesenta.
} 
El estilo gráfico y visual de Art Spiegelman (1948) en Maus, quien como hemos señalado es sin duda un precursor o incluso fundador temprano de este movimiento, obedece a las necesidades expresivas y narrativas de su relato. La FIG. 18 pertenece a dicha obra:
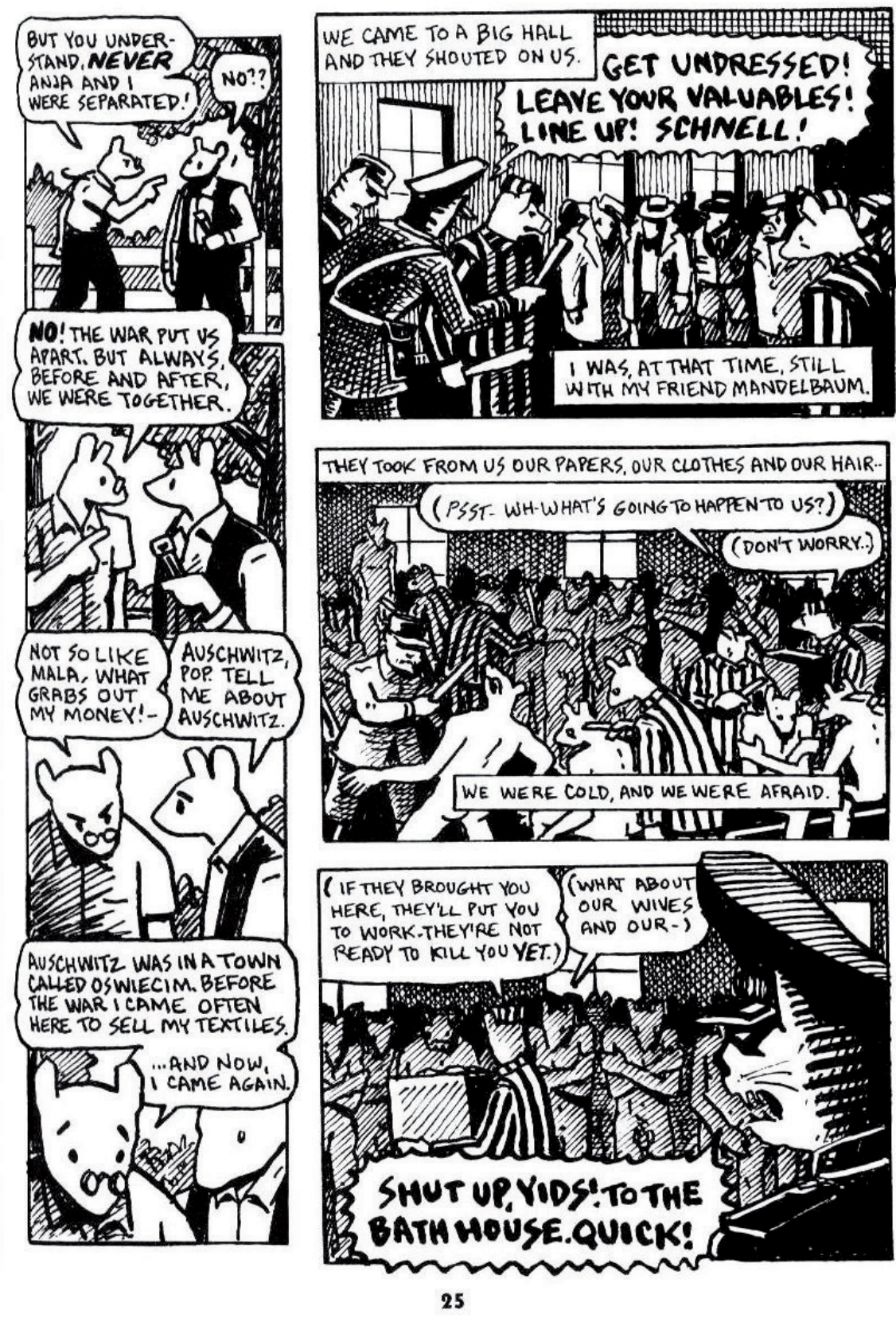

FIG. 18. Maus, Art Spiegelman, 1991.

En Maus el autor nos narra la historia de su padre, judío superviviente del campo de exterminio de Auschwitz, en una narración que fluye entre la evocación histórica de Vlad Spiegelman y la conflictiva relación paterno filial en tiempo presente, conformando un cómic que trasciende el género de la memoria del holocausto (sin dejar de serlo, por supuesto), para imbricar memoria y costumbrismo, denuncia histórica y autobiografía de un modo inaudito.

El horror del genocidio nazi está plasmado no con un acabado virtuoso y naturalista, sino mediante una búsqueda formal del adecuado tono gráfico. La tosquedad aparente del dibujo se revela el modo necesario para transmitir dicho horror, pues adquiere connotaciones simbólicas al eliminar concienzudamente rasgos de de- 
talle en la representación gráfica sin prescindir de formas visuales de marcado carácter expresionista. Incluso en la idea metafórica de la solución representativa, esto es la plasmación de estos ratones/judíos y gatos/nazis podría buscar un estilo muy diferente. Pero Spiegelman opta por una iconicidad de rasgos básicos que no obstante sabe cuidar las masas de negro y las tramas manuales, esos rayados que usa tanto para dar toques de iluminación como para alejar el segundo plano en un efecto de cortinas humanas, o mejor, deshumanizadas, en las viñetas donde se reflejan los modos y la barbarie de los campos de concentración (por tanto, más que sombra, nos hallamos ante una expresión de cierto estado emocional latente en toda la obra).

Maus ha generado una corriente, donde los recursos visuales pueden parecer relegados a un segundo plano (y hemos visto que lo textual en el cómic es tan gráfico como el propio dibujo). No es cierto y Spiegelman demuestra que la aparente tosquedad es el resultado de un concepto visual muy trabajado, pero a ojos de según qué lectores, persiste a veces una idea de "mal dibujo" en la novela gráfica. Es más, ante la idea de un cómic de autor que se pueda medir por ciertos tópicos relativamente frecuentes (tono ensimismado, interiorismo emocional, trascendencia del mundo interior frente a la acción externa...), podríamos llegar a imaginar que el resultado de un acabado gráfico conceptual sumado a relatos íntimos es un patrón en el que la letra escrita sufre un retroceso en el empleo de sus muchos, inventivos y sin duda notables recursos gráficos, visuales. Sin embargo ni la novela gráfica se restringe a dos axiomas tal que dibujo supuestamente sencillo y tono narrativo contemplativo, ni por supuesto los novísimos autores dejan de reivindicar los recursos específicos del medio para hacerlos evolucionar.

En otras épocas la voluntad de ennoblecer al cómic pasó también por buscar tonos y temas poco apropiados para la infancia (sexo, hiperviolencia, rebeldía). Esto es, ardides argumentales. O bien por incrementar el peso de lo literario, recargando innecesariamente las páginas de textos de apoyo, relegando a la imagen al papel indebido de reiterativa y neutra ilustración. También hubo un furor por la tendencia pictórica presuntamente ennoblecedora y que, a menudo olvidando los rudimentos de la narración gráfica, se dedicó a sobrecargar de texturas plásticas y referencias a la pintura contemporánea los cómics, sin cuidar la esencia real del medio. ${ }^{5}$ Pero los nuevos espeleólogos del lenguaje comicográfico han atendido, esta vez sí, a los maestros del pasado, retrotrayéndose incluso a aquellos creadores de los principios del cómic que, aún ajenos al influjo del cine, dieron a la historieta su particular gramática. ${ }^{6}$ Por tanto, la novela gráfica abunda en soluciones excitantemente nuevas para el arte de mezclar lo textual con lo icónico ajenas a otras artes, y además inspiradas en los grandes maestros de la historieta y en la historia del cómic. Se reivindica el medio propio como fuente básica para su crecimiento, y se logran nuevas maneras de emplear la grafía, con lo que el cómic se renueva desde dentro.

La FIG. 19 corresponde a una página de Lint, de Chris Ware (1967). En ella podemos observar un perfecto dominio de los diálogos: la letra escrita aplica ideas ya analizadas como el efecto enfático o los diferentes tamaños de la fuente, y a través de los globos y las líneas de diálogo se crea un paisaje de espacios en off de rica complejidad. Pero sobre todo merece la pena señalar el uso de la letra en lo que no es exactamente cartela, ni mucho menos onomayopeya, sino una suerte de monólogo interior que se materializa literalmente, hasta convertirse en diegético. "Estoy asqueado de todo", piensa Lint, y el "I" que es la primera persona del singular en inglés nace ante él, en la segunda viñeta. Ware, en cierto modo, toma las lexías y los logros de Will Eisner al respecto, en sus famosas primeras páginas de The Spirit y los lleva mucho más allá, haciendo del diseño algo revolucionario y totalmente novedoso en el cómic (el diseño de la grafía, pero también del propio dibujo, y de la página como un todo donde sus partes se imbrican y trascienden cualquier orden secuencial).

\footnotetext{
5 No se entiendan estos ejemplos como las únicas vías adoptadas por el cómic adulto en épocas pretéritas, sino como ilustración de ensayos, formas de intentarlo. Y a mi juicio, resbaladizas, peligrosas e incluso equivocadas, pese a gozar, en determinados momentos y épocas, de mucha celebración crítica. Era el "ennoblecimiento" del cómic, pero por un mal camino. Acercándolo a otros artes innecesariamente (aunque hay ocasiones y hemos visto ejemplos, en que la mezcla ha sido pertinente y ha logrado excelentes resultados).

${ }^{6}$ El peso de los modos cinematográficos es evidente y ha sido norma, sobre todo desde el advenimiento del tono realista en las tiras de prensa de la Edad de Oro, donde los modelos de encuadre o la planificación de planos y escenas del cine influyeron en la historieta.
} 


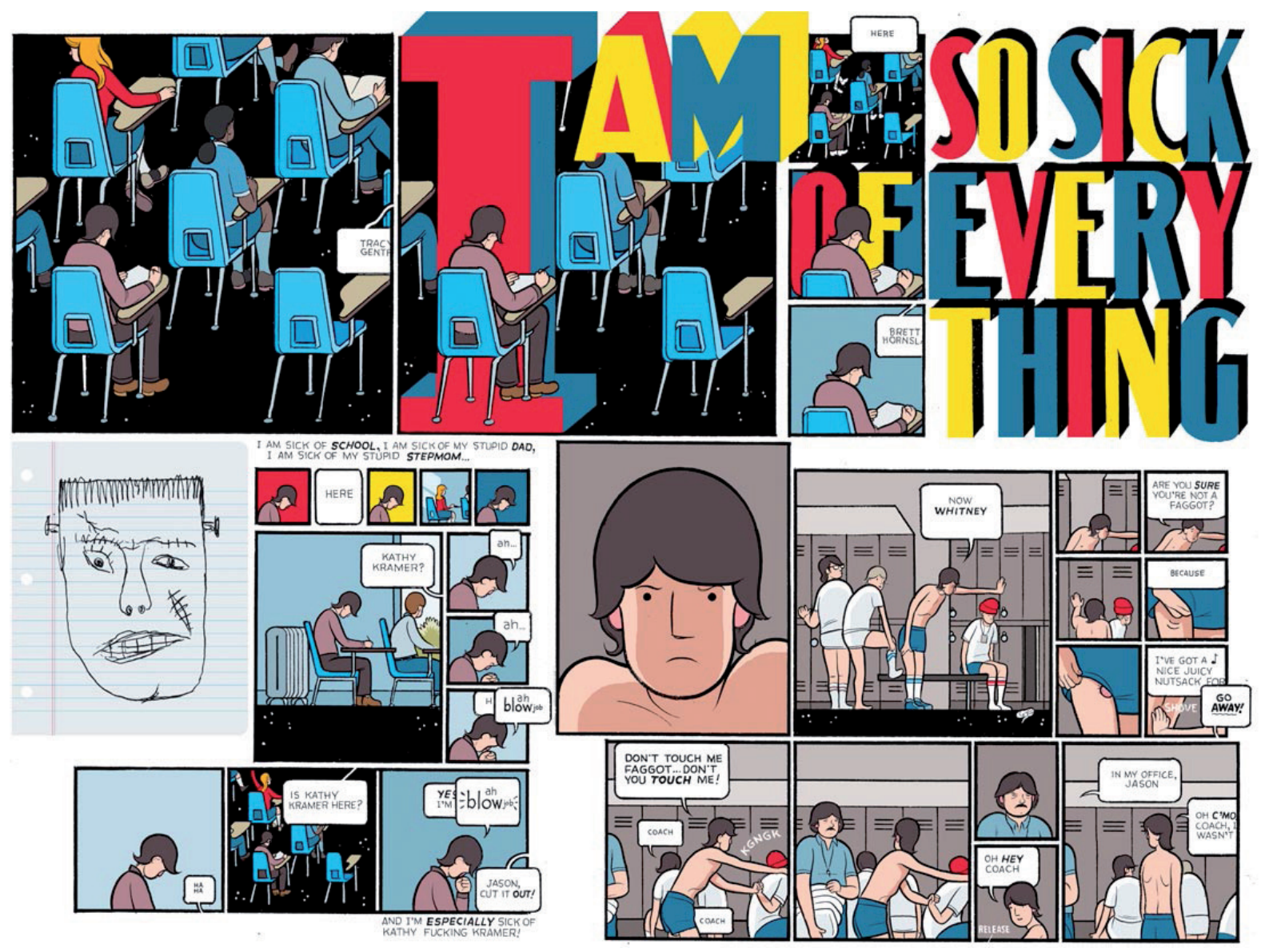

FIG. 19. Lint, Chris Ware, 2010.
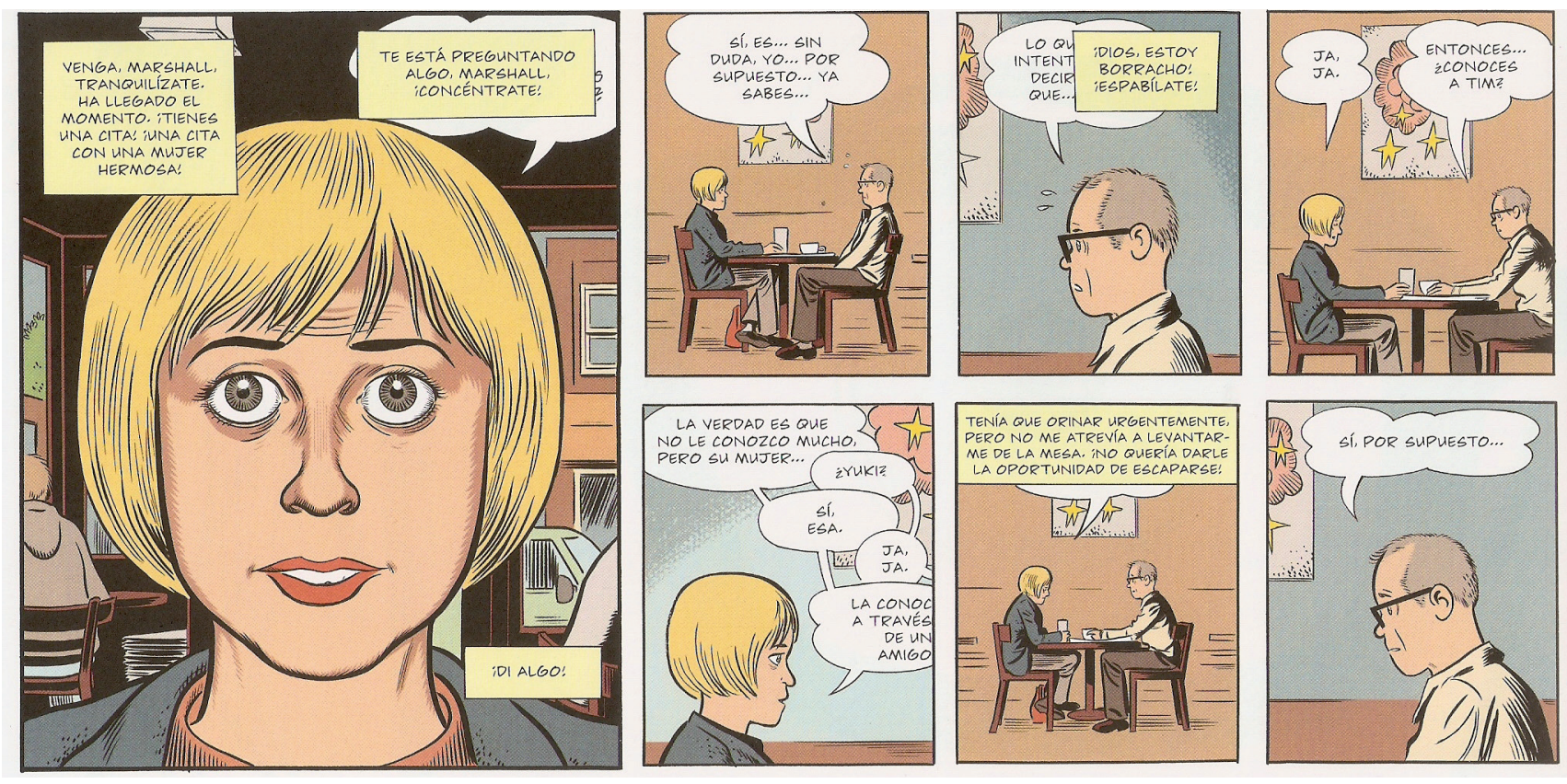

FIG. 20. Mister Wonderful, Daniel Clowes, 2011. 
En esta línea, aunque de un modo más moderado y si se quiere sutil, ha trabajado Daniel Clowes en Mister Wonderful, del que extraemos el ejemplo de la FIG. 20.

Aquí las cartelas y los bocadillos adquieren una naturalza novedosa que también usa Ware en Lint, pero que resulta aún más explícita. Esta naturaleza de las cartelas no es exactamente diegética tal que si fuesen elementos corpóreos de la acción, pero sí resultan expresivas y narrativas, ya que se ubican estratégicamente solapándose las unas a las otras para constituir así un mensaje narrativo independientemente de lo que el propio texto exprese. La escena relata una primera cita a ciegas, contada desde el punto de vista del varón, cuyo monólogo interior se construye en los cartuchos (ejemplo por tanto de cartelas con un texto que evita al narrador omnisciente y acude a las líneas de pensamiento, monólogo interior, del protagonista). Y al cubrir con ellos los globos de diálogo, tanto los propios como los de la mujer, antepone los miedos, sensaciones e inseguridades internas a la acción externa. Lo importante, evidentemente, no está aquí en la caligrafía sino en la ubicación de la letra y cómo se emplean esos elementos gráficos de un modo estratégico. Digamos que la ubicación de la letra escrita cobra aquí un nuevo valor, entre la diégesis y el contenido narrativo.

El presente, estamos viendo, es rico en el sabio empleo de los recursos propios del cómic como arte, y los autores más pujantes siguen investigando vías expresivas. Un último ejemplo de interacción de lo textual y la imagen dibujada lo encontramos en Habibi de Craig Thompson (1975). Esta novela gráfica de seiscientas setenta y dos páginas podría ser objeto de un estudio pormenorizado en lo que a recursos de narración comicográfica respecta, y capítulo nada menor sería el papel de la letra escrita en su seno.

Obra sobre el amor en el entorno de la cultura (y la mítica ancestral) islámica, supone un libro donde lo atávico, la narrativa oriental clásica y el mundo contemporáneo se funden en un trabajo que tiene muy

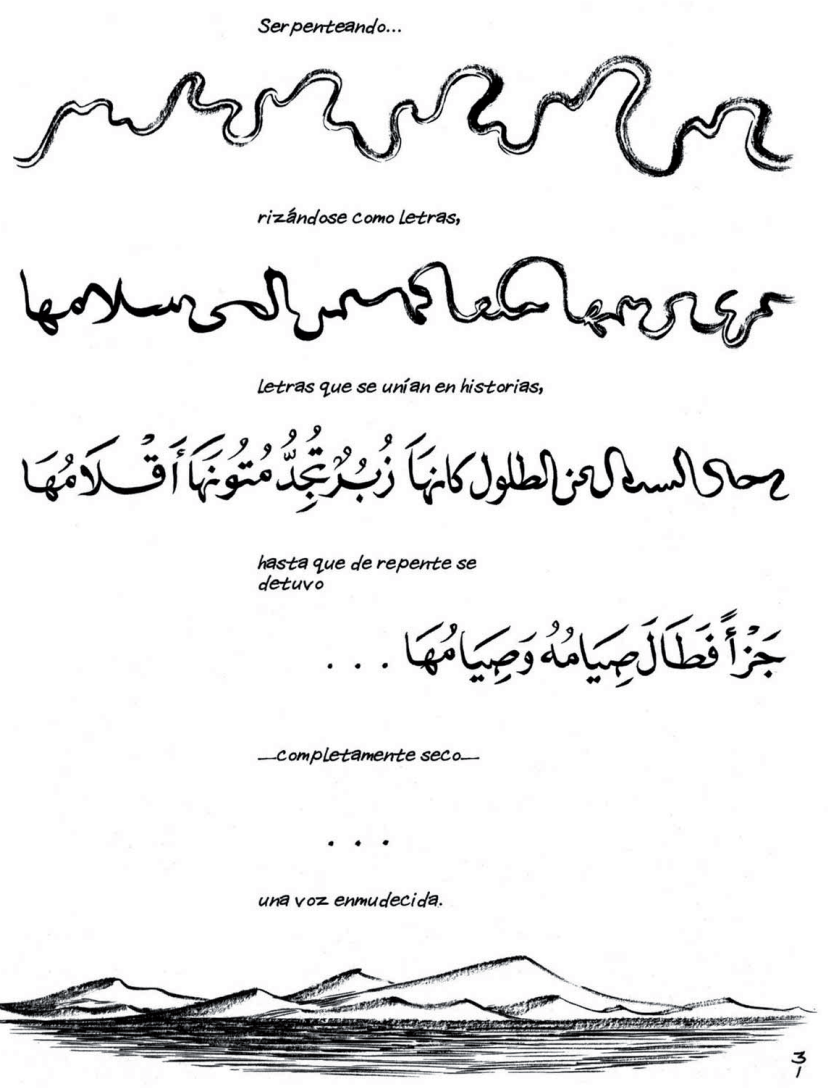

FIG. 20. Habibi, Craig Thompson, 2011 
presente la impronta del arte árabe, ornamental y abstracto. La filigrana y la letra escrita se utilizan en Habibi a veces indistintamente, pero siempre por un motivo concreto, expresivo, decorativo e incluso narrativo, y siempre aporta información y narración. En el ejemplo (FIG. 21) lo vemos con claridad:

En la escena previa a esta página de Habibi se habla de un río y su naturaleza oscilante y fluctuante. Mutable. Y aquí se continúa explicando la historia de ese río, que se reseca, unido al desierto, extinguido. Al mismo tiempo Thompson lo compara con la capacidad escritora y la naturaleza humana, que nos convierte en perpetuos contadores de historias. El río se retuerce como se retuercen las letras de un texto que nos cuenta un relato, y esa historia también puede interrumpirse, en puntos suspensivos. Pasamos de un río fluctuante a un texto, un cuento que muere en una línea de puntos suspensivos, como muere el río en medio de un desierto que lo absorbe todo. Y lo que leemos en esta página, de hecho, es la historia que cuenta una mujer a un muchacho.

\section{Conclusión.}

Estos ejemplos permiten concluir que, en tanto que recurso narrativo, la letra escrita es parte enriquecedora del lenguaje del comic en una enorme diversidad de aspectos y matices. Y que la escritura dentro de la historieta ha evolucionado hasta un presente donde continúa siendo utilizada como un elemento capital para poder calibrar la riqueza del medio. Un arte joven y vivo, pese a sus muchos años de existencia, que sigue aprendiendo a crecer sobre sus propias bases.

No sería exagerado augurar una nueva edad de oro en el futuro próximo del noveno arte. Es cierto que el tiempo en que era una novedad en los medios de entretenimiento popular queda muy lejos, tanto como su naturaleza de consumo masivo y de generador de iconos de la narrativa contemporánea. Pero todo ello, o su supuesta reubicación en el abanico de medios de los mass media en un papel secundario o elitista, no interfiere con sus enormes capacidades artísticas y las posibilidades del cómic de cara a su evolución y crecimiento. Tiene mucho camino que recorrer, escalar posiciones en la ardua carrera de la normalización social y cultural, pero para lograrlo debe pensarse a sí mismo como arte único para seguir evolucionando. La aplicación creativa y narrativa de la letra escrita en la historieta demuestra, a través de un único aspecto, que los recursos del cómic como medio artístico son intrasferibles y dueños de una gran riqueza, que merece atención, estudio y desarrollo. El cómic solo necesita, en fin, su propia gramática para seguir creciendo en el futuro. Y ser consciente de ella, de sus posibilidades aún en desarrollo. 